\title{
RADIOCARBON CALIBRATION/COMPARISON RECORDS BASED ON MARINE SEDIMENTS FROM THE PAKISTAN AND IBERIAN MARGINS
}

\author{
Edouard Bard ${ }^{1,2} \cdot$ Guillemette Ménot $^{1} \bullet$ Frauke Rostek $^{1} \bullet$ Laetitia Licari $^{1} \bullet$ Philipp Böning $^{1} \bullet$ \\ R Lawrence Edwards ${ }^{3} \cdot$ Hai Cheng ${ }^{3,4} \bullet$ Yongjin Wang $^{5} \bullet$ Timothy J Heaton $^{6}$
}

\begin{abstract}
We present a new record of radiocarbon ages measured by accelerator mass spectrometry (AMS) on a deepsea core collected off the Pakistan Margin. The ${ }^{14} \mathrm{C}$ ages measured on the planktonic foraminifera Globigerinoides ruber from core MD04-2876 define a high and stable sedimentation rate on the order of $50 \mathrm{~cm} / \mathrm{kyr}$ over the last $50 \mathrm{kyr}$. The site is distant from the main upwelling zone of the western Arabian Sea where ${ }^{14} \mathrm{C}$ reservoir age is large and may be variable. Many independent proxies based on elemental analyses, mineralogy, biomarkers, isotopic proxies, and foraminiferal abundances show abrupt changes correlative with Dansgaard-Oeschger and Heinrich events. It is now common knowledge that these climatic events also affected the Arabian Sea during the last glacial period through changes in the Indian monsoon and in ventilation at intermediate depths. The stratigraphic agreement between all proxies, from fine- to coarse-size fractions, indicates that the foraminiferal ${ }^{14} \mathrm{C}$ ages are representative of the different sediment fractions.
\end{abstract}

To build a calendar age scale for core MD04-2876, we matched its climate record to the oxygen isotopic $\left(\delta^{18} \mathrm{O}\right)$ profile of Hulu Cave stalagmites that have been accurately dated by U-Th (Wang et al. 2001; Southon et al. 2012; Edwards et al., submitted). Both archives exhibit very similar signatures, even for century-long events linked to monsoonal variations. For comparison, we have also updated our previous work on core MD95-2042 from the Iberian Margin (Bard et al. 2004a,b,c), whose climate record has likewise been tuned to the high-resolution $\delta^{18} \mathrm{O}$ Hulu Cave profile. Sophisticated and novel statistical techniques were used to interpolate ages and calculate uncertainties between chronological tie-points (Heaton et al. 2013, this issue). The data from the Pakistan and Iberian margins compare well even if they come from distant sites characterized by different oceanic conditions. Collectively, the data also compare well with the IntCal09 curve, except for specific intervals around $16 \mathrm{cal}$ kyr BP and from 28 to $31 \mathrm{cal}$ kyr BP. During these intervals, the data indicate that ${ }^{14} \mathrm{C}$ is somewhat older than indicated by the IntCal09 curve. Agreement between the data from both oceanic sites suggests that the discrepancy is not due to local changes of sea-surface ${ }^{14} \mathrm{C}$ reservoir ages, but rather that the IntCal09 curve needed to be updated in these intervals as has been done in the framework of IntCal13 (Reimer et al. 2013a, this issue).

\section{INTRODUCTION}

The atmospheric ${ }^{14} \mathrm{C} /{ }^{12} \mathrm{C}$ ratio varies with time, an observation that conflicts with the main assumption of radiocarbon dating (Libby 1952). In order to calculate accurate ages, atmospheric ${ }^{14} \mathrm{C}$ fluctuations must be adjusted by means of a calibration curve. Such curves are obtained by comparing raw ${ }^{14} \mathrm{C}$ ages, assuming a constant atmospheric ${ }^{14} \mathrm{C} /{ }^{12} \mathrm{C}$ ratio, with true calendar ages derived from independent dating methods. Several approaches have been used to construct the internationally agreed ${ }^{14} \mathrm{C}$ calibration curve dependent upon the relative availability of calibration-quality data over the wide range of times at which we wish to calibrate.

For the Holocene period, abundant subfossil tree remains have been used to produce a high-resolution atmospheric curve by comparing ${ }^{14} \mathrm{C}$ ages and dendrochronology dates from the same tree sections (Stuiver et al. 1998; Reimer et al. 2004, 2009). It is difficult to extend this "dendrocalibration" much further because of the scarcity of fossil trees from the last glacial period. Consequently, other types of archives have been proposed to extend the calibration: these records include annually laminated sediments (e.g. Goslar et al. 1995; Hughen et al. 1998; Bronk Ramsey et al. 2012) and shallow-

\footnotetext{
${ }^{1}$ CEREGE, Aix-Marseille University, CNRS, IRD, Collège de France, Technopôle de l'Arbois, BP 80, F-13545 Aix-enProvence, France.

${ }^{2}$ Corresponding author. Email: bard@cerege.fr.

${ }^{3}$ Department of Earth Sciences, University of Minnesota, Minneapolis, Minnesota 55455-0231, USA.

${ }^{4}$ Institute of Global Environmental Change, Xi'an Jiaotong University, Xi'an 710049, China.

${ }^{5}$ College of Geography Science, Nanjing Normal University, Nanjing 210097, China.

${ }^{6}$ School of Mathematics and Statistics, University of Sheffield, Sheffield S3 7RH, United Kingdom.
} 
water corals from tropical islands that can be cross-dated by ${ }^{14} \mathrm{C}$ and uranium-thorium (U-Th) dating (Bard et al. 1990a, 1993, 1998; Edwards et al. 1993; Cutler et al. 2004; Fairbanks et al. 2005; Durand et al. 2013, this issue).

However, it remains particularly difficult to reach back to older periods because residual levels of ${ }^{14} \mathrm{C}$ in samples become extremely low, being of the order of a few percent of the concentration found in modern samples. In addition, old samples have often been altered by various geochemical and diagenetic processes. In particular, corals in this time range grew before the sea level minimum of the last glacial maximum (LGM, 21,000 cal yr BP, Bard et al. 1990b), when they underwent meteoric alteration. Diagenesis creates biases for both U-Th and ${ }^{14} \mathrm{C}$, often precluding their use for ${ }^{14} \mathrm{C}$ calibration purposes.

In complement to samples cross-dated by varve counting or by the U-Th method, several authors (Voelker et al. 2000; Hughen et al. 2004a,b, 2006; Bard et al. 2004a,b,c; Shackleton et al. 2004) have used deep-sea sediments whose stratigraphy can be tied to well-dated climate records such as the Greenland Summit ice cores (Dansgaard et al. 1993; Stuiver and Grootes 2000) or Chinese stalagmites (Wang et al. 2001). This technique is based on correlating the large-amplitude climatic excursions typical of the last glacial period, which occurred abruptly over periods of decades to centuries and lasted for only a few centuries to millennia (so-called Dansgaard-Oeschger [DO] and Heinrich $[\mathrm{H}]$ events).

In this study, we present a new set of ${ }^{14} \mathrm{C}$ ages obtained on planktonic foraminifera from a deep-sea core collected off the Pakistan Margin (MD04-2876). Several paleoclimatic proxy records measured on this core allow us to build up a chronology based on correlation with the $\delta^{18} \mathrm{O}$ record from U-Th dated stalagmites from Hulu Cave in China. A Gaussian stochastic process has been used to interpolate ages and calculate uncertainties between chronological tie-points. The comparison between ${ }^{14} \mathrm{C}$ and calendar ages is translated into a calibration data set that can be compared with the published IntCal calibration curves and with data from core MD95-2042 collected off the Iberian Margin, whose stratigraphy has been retuned to the same Hulu Cave $\delta^{18} \mathrm{O}$ record.

\section{SAMPLES AND METHODS}

Core MD04-2876 ( $24^{\circ} 51^{\prime} \mathrm{N}, 64^{\circ} 01^{\prime} \mathrm{E}$; $828 \mathrm{~m}$ water depth) was recovered on the Pakistan Margin in 2004 during the MD143 CHAMAK cruise of the R/V Marion Dufresne. The site is located on the Makran continental slope within the present-day oxygen minimum zone (OMZ). Sediments consist mainly of calcareous silty clay with $10-40 \%$ carbonate and $1 \%$ organic carbon. Oceanographical and sedimentological conditions at the site have been previously described (Pichevin et al. 2007; Böning and Bard 2009).

To construct a precise ${ }^{14} \mathrm{C}$ chronology, we selected specimens of the planktonic foraminifera Globigerinoides ruber. This species lived at shallow depth in the Arabian Sea during the Holocene and the glacial period (Ganssen et al. 2011). In order to eliminate adsorbed contamination, the shells were leached prior to hydrolysis (in $2 \mathrm{~mL}$ of $0.01 \mathrm{M}$ nitric acid for $15 \mathrm{~min}$ and with sonication for 5-10 s). This pretreatment was performed either at CEREGE in Aix-en-Provence or at LMC14 in Saclay, France. In the second case (LMC14), the leached shells were left wet before hydrolysis, converting the shells into $\mathrm{CO}_{2}$ (as recommended by Schleicher et al. [1998] and Nadeau et al. [2001]) before being reduced to graphite targets. By contrast, samples leached at CEREGE were dried before further chemical processing. Accelerator mass spectrometry (AMS) analyses were performed at LMC14 with the Artemis national facility (Cottereau et al. 2007; Moreau et al. 2013). 
Blank measurements were analyzed during the course of these foraminifera shell analyses. As routinely done at $\mathrm{LMC14}$, such measurements are performed on a crushed mollusk shell dated to $>100 \mathrm{kyr}$ (mean and standard deviation are $0.22 \pm 0.09 \mathrm{pMC}$ based on 7 samples). Blank values were used in the calculation of ${ }^{14} \mathrm{C}$ ages, together with an overall uncertainty of $40 \%$ propagated in the age error calculation. Core MD04-2876 is only $25 \mathrm{~m}$ long, with an average sedimentation rate of $50 \mathrm{~cm} / \mathrm{kyr}$, which does not allow sampling of foraminifera much older than $50 \mathrm{kyr}$. Therefore, we also picked G. ruber shells from a nearby core collected during the same cruise. Core MD04-2873 has a lower sedimentation rate and is longer than MD04-2876 (34 m), which enabled us to collect G. ruber shells corresponding to an age $>250 \mathrm{kyr}$ BP (older than marine isotope stage [MIS] 7). The value of $0.25 \pm 0.04 \mathrm{pMC}$ is compatible with blank measurements on the fossil mollusk and is in line with results from other laboratories (e.g. Nadeau et al. 2001).

The overall reproducibility of ${ }^{14} \mathrm{C}$ age determination can be assessed by considering 13 pairs of adjacent samples taken a few $\mathrm{cm}$ apart in the core (Table 1). This test is particularly stringent because these foraminifera samples were not homogenized and thus do not represent true analytical replicates. Even with this extra source of variability, 12 pairs of "duplicates" agree within $1 \sigma$ errors. The results for 1130 and $1130.5 \mathrm{~cm}$ agree within $2 \sigma$. Moreover, these 13 pairs of foraminifera samples were leached either at CEREGE (followed by hydrolysis of dried shells) or at LMC14 (followed by hydrolysis of wet shells). No significant bias could be attributed to this difference in pretreatment. (Note that for the depth of $1130 \mathrm{~cm}$, the analysis with leaching at CEREGE provided the oldest numerical age, but both ages agree within $2 \sigma$.) Nevertheless, our test is still preliminary and systematic experiments will be performed in order to understand the role of leaching.

Figure 1 shows the ${ }^{14} \mathrm{C}$ ages plotted versus depth in core MD04-2876. At this scale, the duplicates are indistinguishable from each other. Collectively, the ${ }^{14} \mathrm{C}$ ages define a rather smooth sediment curve that can be approximated with a polynomial fit $\left(r^{2}>0.999\right.$ is obtained with polynomial equations of degree $>5$ ). Only the ${ }^{14} \mathrm{C}$ data at $680.5 \mathrm{~cm}$ diverge significantly from the polynomial fit. Nevertheless, this raw ${ }^{14} \mathrm{C}$ age of $11,110 \pm 50 \mathrm{BP}$ (with reservoir age correction) does not produce an age reversal with the other ${ }^{14} \mathrm{C}$ data (Figure 1). The stratigraphy of core MD04-2876 (discussed below) shows that this sample belongs to the Bølling period whereas its ${ }^{14} \mathrm{C}$ age corresponds to the Late Allerød. Consequently, this isolated ${ }^{14} \mathrm{C}$ result can be considered as an outlier and will be discarded from further discussion.

Core MD04-2876 is partly laminated and characterized by a high sedimentation rate of about $50 \mathrm{~cm} / \mathrm{kyr}$, as shown in Figure 1. This should minimize the influence of bioturbation, in particular the mixing bias between different size fractions. As calculated by Bard (2001), such a bias would be on the order of a few decades for such a sedimentation rate. As described below, a further indication that foraminifera ${ }^{14} \mathrm{C}$ ages are representative of the different sediment fractions is that all paleoceanographic proxies are in stratigraphic agreement in core MD04-2876.

For the sake of comparison with MD04-2876 data, Figure 2 shows the age-depth record for core MD95-2042 from the Iberian Margin. This data set, used previously by Reimer et al. (2009), updates records published by Bard et al. (2004a,b,c) and Shackleton et al. (2004). Table 1 provides the compilation of ${ }^{14} \mathrm{C}$ ages measured on G. bulloides. Ages indicated in bold were measured after the compilation by Bard et al. (2004c). These samples were leached with diluted nitric acid either at CEREGE or NOSAMS (WHOI). Blanks subtracted from these analyses were based on ${ }^{14} \mathrm{C}$ measurements in foraminifera samples corresponding to a section of the core, which is older than MIS 5e ( $>130 \mathrm{kyr}$ BP; mean and standard deviation are $0.32 \pm 0.05 \mathrm{pMC}$ based on 6 G. bulloides samples with no significant differences between samples leached at CEREGE or NOSAMS). Attempts to obtain meaningful ages for samples deeper than $1600 \mathrm{~cm}$ in core MD95-2042 remain unsuccessful. 


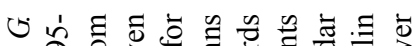

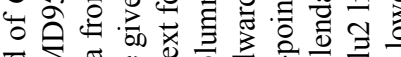

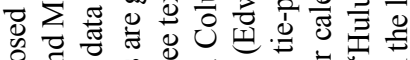

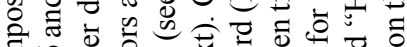

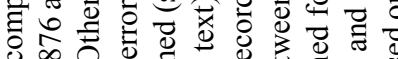
0 ○ 0 过

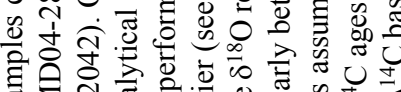

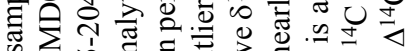

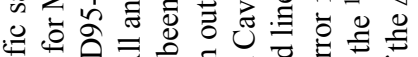

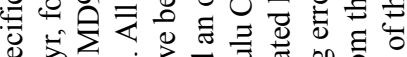

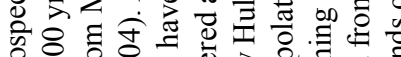

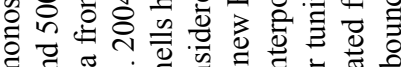

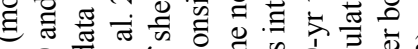

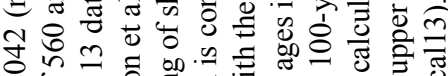

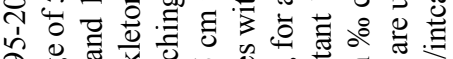

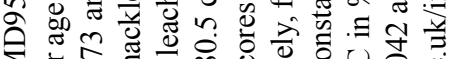

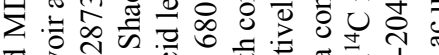

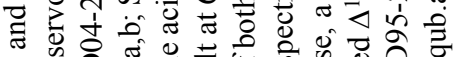

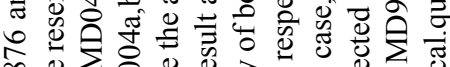

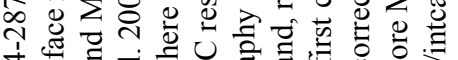

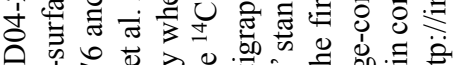

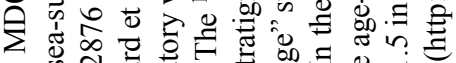

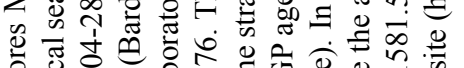

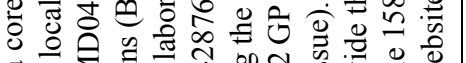

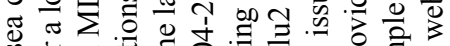

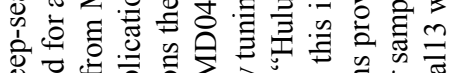

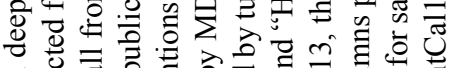

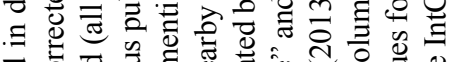
ठ ठ ठ

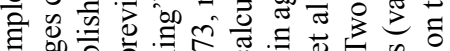

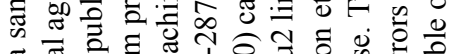

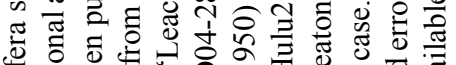

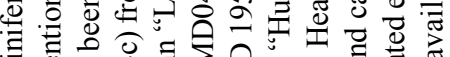

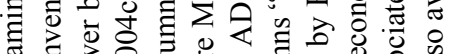

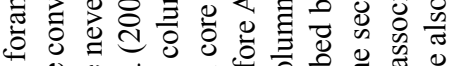

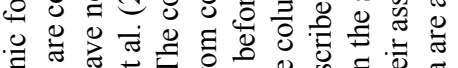

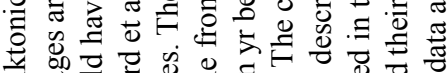
亲

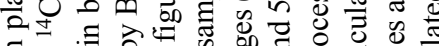

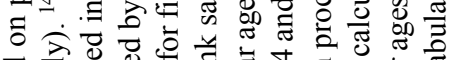
च

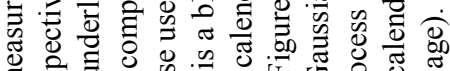

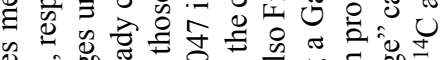

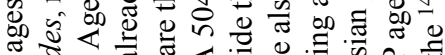
U气

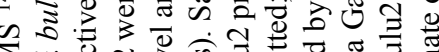

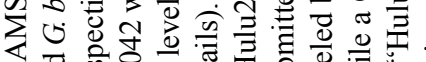

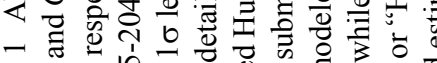

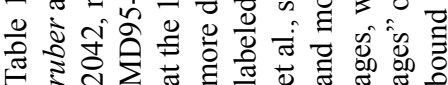

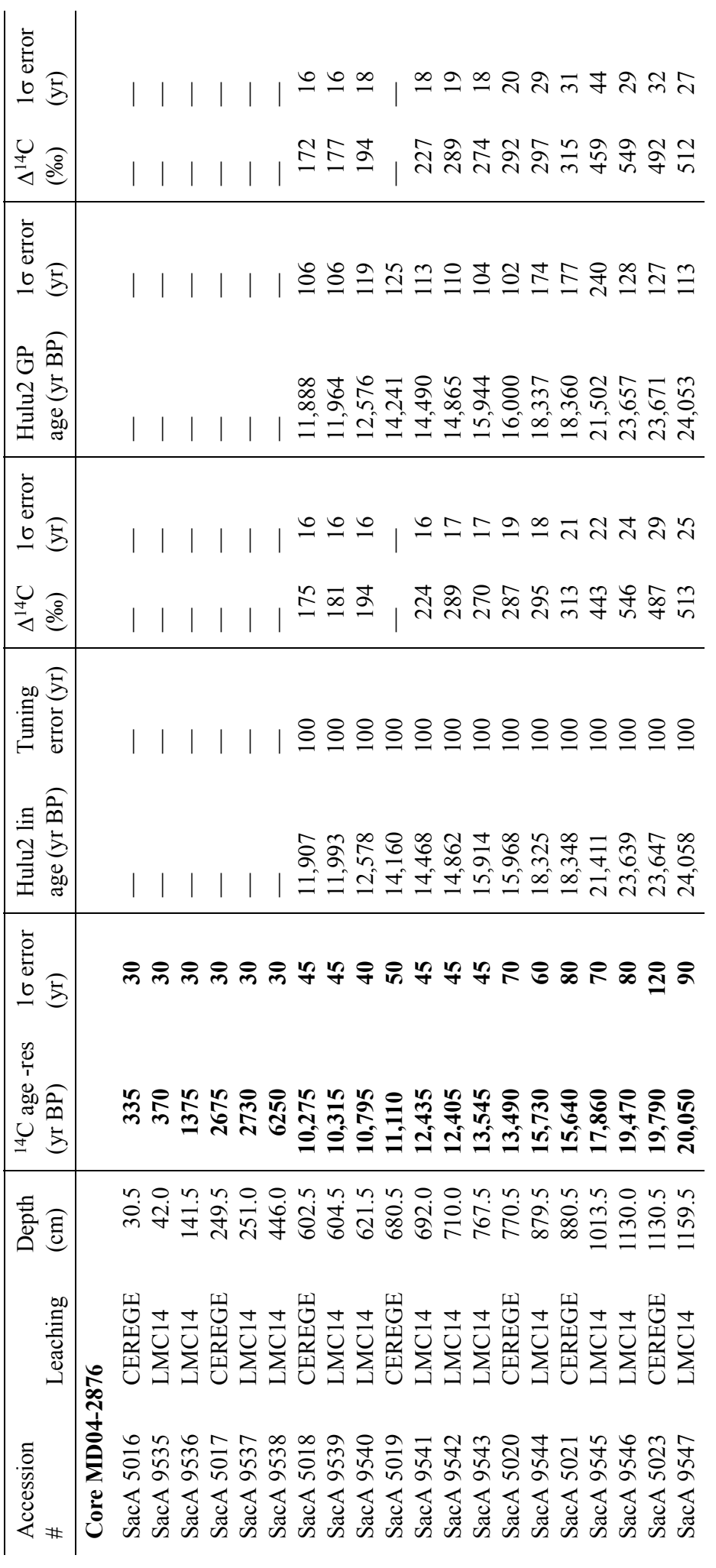




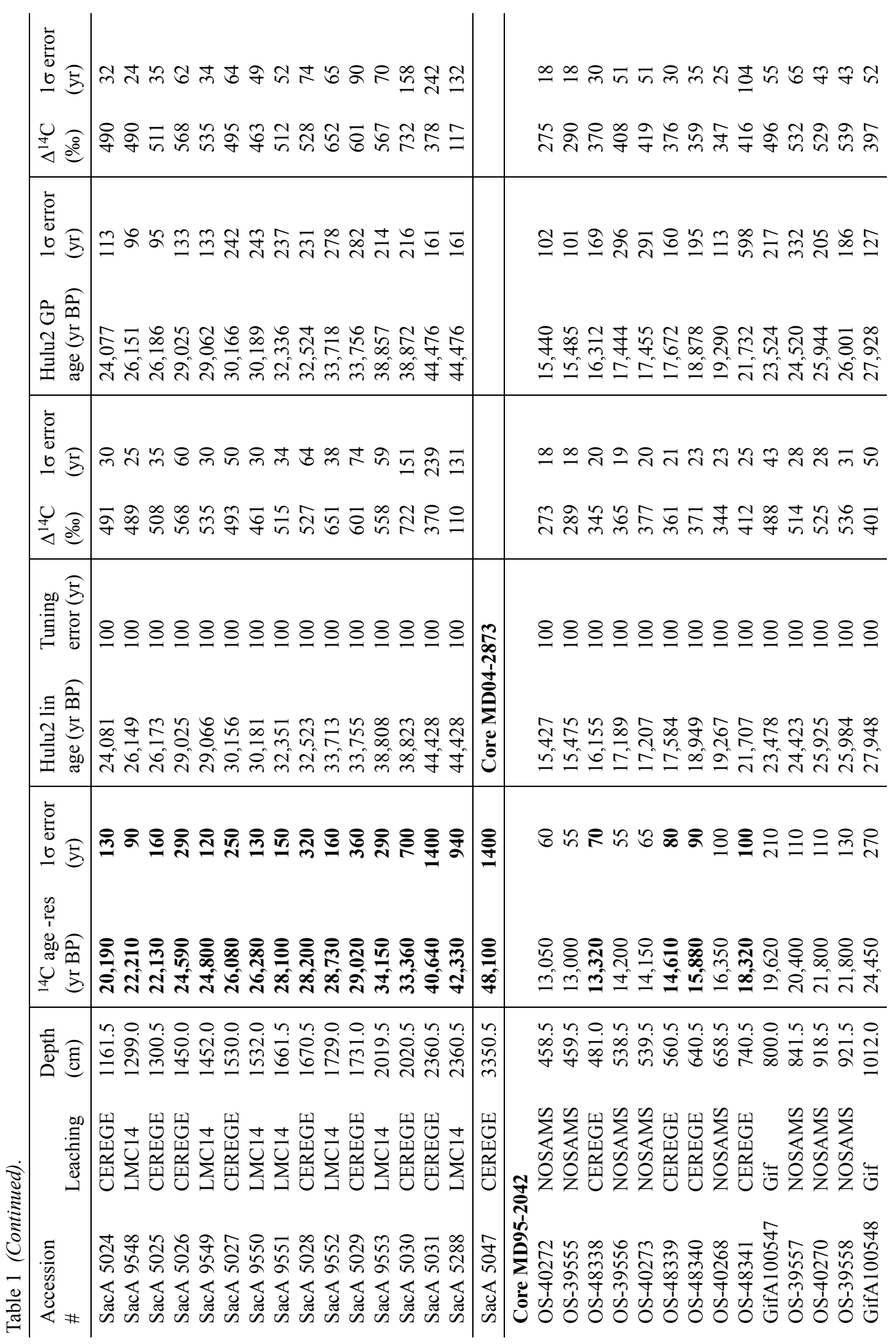




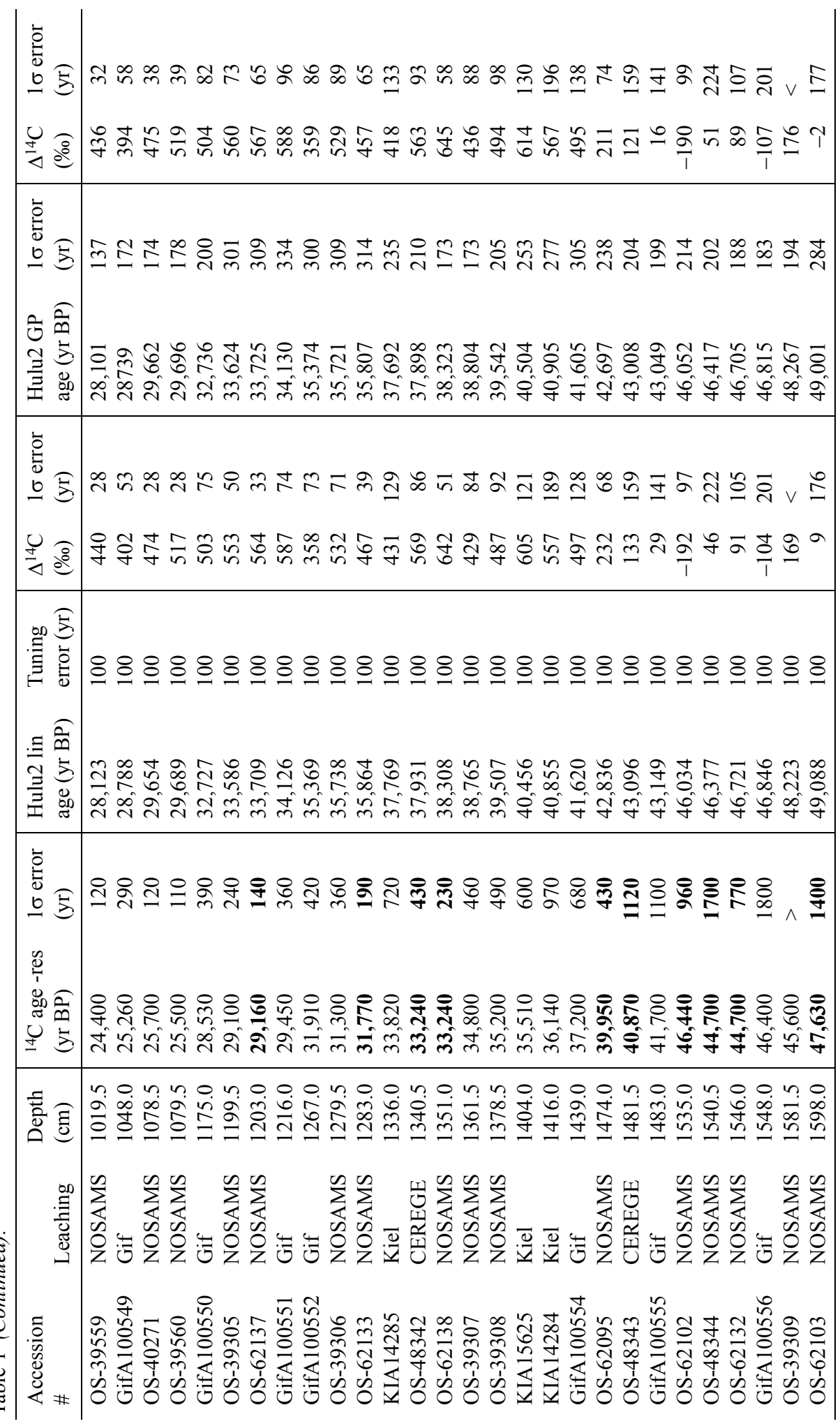




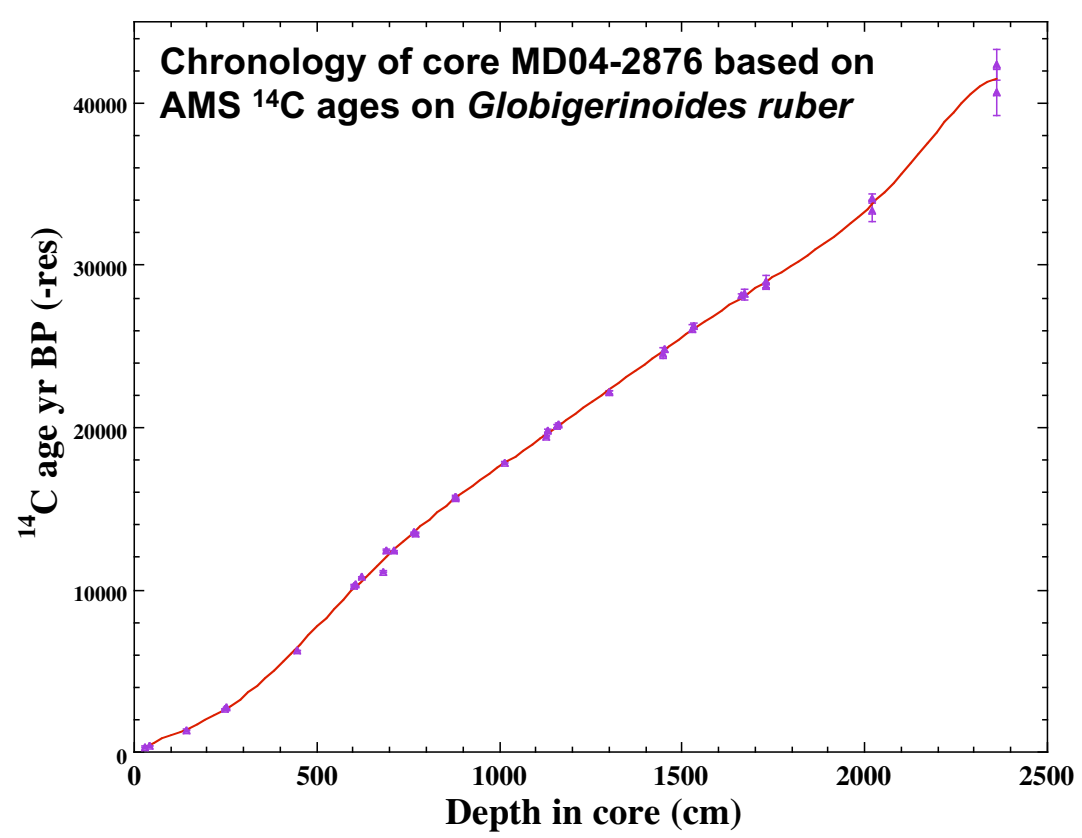

Figure $1{ }^{14} \mathrm{C}$ ages plotted versus depth in core MD04-2876 from the Pakistan Margin (numerical data from Table 1). Uncertainties are plotted at the $1 \sigma$ level. Overall, the ${ }^{14} \mathrm{C}$ data define a high sedimentation rate of $\sim 50 \mathrm{~cm} / \mathrm{kyr}$ and are approximated with a degree 8 polynomial fit (red line, $r^{2}>0.999$, such high values are obtained with degree $\left.>5\right)$. The ${ }^{14} \mathrm{C}$ datum at $680 \mathrm{~cm}$ diverges significantly and is considered an outlier.

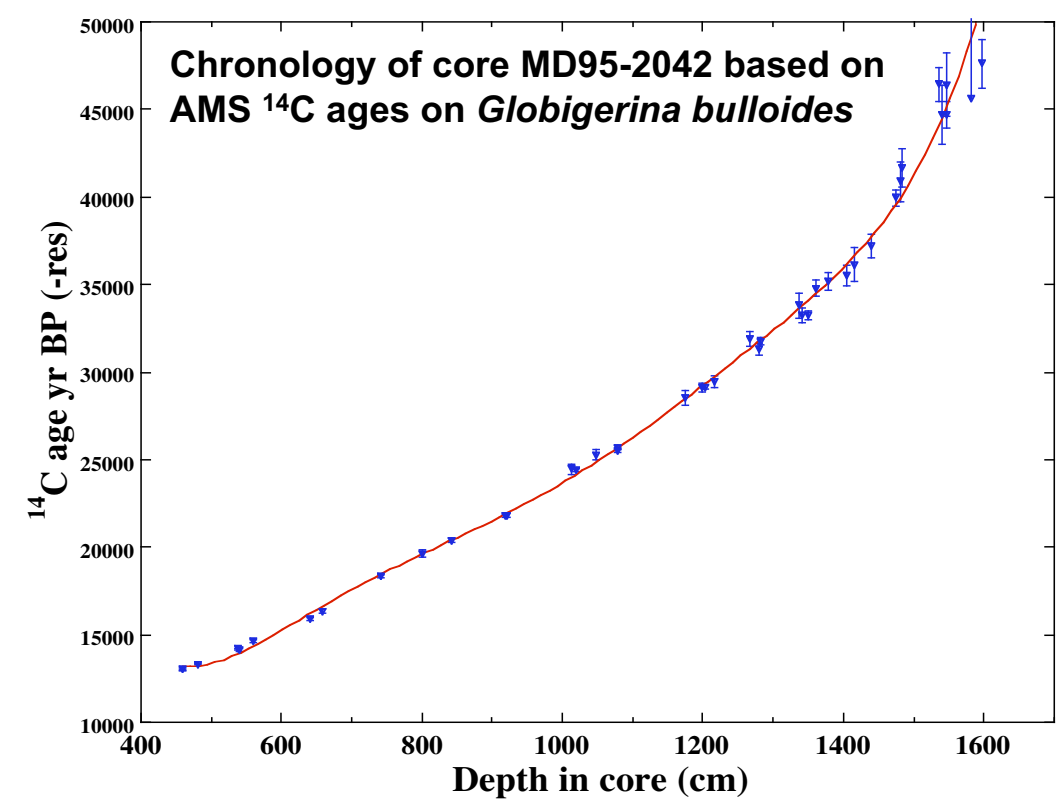

Figure $2{ }^{14} \mathrm{C}$ ages plotted versus depth in core MD95-2042 from the Iberian Margin (numerical data from Table 1). Uncertainties are plotted at the $1 \sigma$ level. Overall, the ${ }^{14} \mathrm{C}$ data define a high sedimentation rate of $\sim 30 \mathrm{~cm} / \mathrm{kyr}$ and can be approximated with a polynomial fit (red line, degree $6, r^{2}>0.99$ ). 


\section{RESERVOIR AGES AND THEIR TEMPORAL VARIABILITY}

${ }^{14} \mathrm{C}$ ages obtained on planktonic foraminifera from deep-sea sediments must be corrected for the difference in ${ }^{14} \mathrm{C}$ composition between the atmosphere and the sea surface. In the modern ocean, the reservoir age applicable to carbonate shells formed in surface waters varies between 300 and $1200 \mathrm{yr}$ and depends mainly on latitude (see Bard 1988; Reimer and Reimer 2001).

It is generally considered that wind speeds were higher during the last glacial period as a response to a steepened temperature gradient between low and high latitudes (Rea 1994; McGee et al. 2010). Increasing the wind-speed velocity by $50 \%$ on average would increase the $\mathrm{CO}_{2}$ piston velocity, thereby leading to a reduction of the reservoir age by $\sim 250 \mathrm{yr}$ (Bard 1988). This first-order calculation based on a box diffusion model is certainly a maximum value, as increased wind speed also favors mixing with older water from below the surface box. In addition, the atmospheric $\mathrm{CO}_{2}$ concentration was lower during the glacial period (190 vs. $280 \mathrm{ppm}$, Lourantou et al. 2010), which led to an increase of the reservoir age by $\sim 175 \mathrm{yr}$ for the full change between LGM and Holocene values (Bard 1988, 1998).

In addition to these global changes, which partly cancel out, we also need to take into account the possibility of local variations in ${ }^{14} \mathrm{C}$ reservoir ages linked to regional paleoceanographic changes. Indeed, several studies show that local reservoir ages have varied in the past, in phase with paleoceanographic changes (Southon et al. 1990; Bard et al. 1994; Austin et al. 1995; Haflidason et al. 1995; Sikes et al. 2000; Siani et al. 2001; Waelbroeck et al. 2001; Bondevik et al. 2006).

For the Pakistan Margin core MD04-2876, we adopt the ${ }^{14} \mathrm{C}$ reservoir age determined by Dutta et al. (2001), based on recent shells collected in the northeastern Indian Ocean. The value is $560 \mathrm{yr}$, i.e. $160 \mathrm{yr}$ older than the classical ocean surface reservoir age of $400 \mathrm{yr}$. This positive $\Delta \mathrm{R}$ corresponds to water column mixing linked to the NE monsoon and/or to the advection of water upwelled during the southwest monsoon. This reservoir age value is compatible with the estimate of $640 \mathrm{yr}$ by von Rad et al. (1999) based on $2{ }^{14} \mathrm{C}$ measurements on century-old varved sediments.

Dutta et al. (2001) quote an uncertainty of $30 \mathrm{yr}$ for their reservoir age estimate, but a larger value may be adopted in order to take into account possible changes through time. By making the hypothesis that Holocene age ${ }^{14} \mathrm{C}$ plateaus in the tree-ring record left equivalent structures in the age-depth relationships of marine sediments, Staubwasser et al. (2002) calculated that the Arabian Sea ${ }^{14} \mathrm{C}$ reservoir age could have been as high as $800-1100$ yr during the early Holocene. Nevertheless, this period was characterized by a maximum of the southwest monsoon whereas the SW monsoon influence was lower during the glacial period (Cheng et al. 2012 and references therein). This was indeed the assumption made by von Rad et al. (2003) who applied a correction of $400 \mathrm{yr}$ for their results on glacial Arabian Sea sediments. For core MD04-2876, a rather large uncertainty of about $\pm 200 \mathrm{yr}$ could thus be assumed to encompass a range of reservoir age values between 360 and $760 \mathrm{yr}$.

As discussed in Bard et al. (2004c) and Shackleton et al. (2004), a reservoir age correction of $500 \mathrm{yr}$ was applied to ${ }^{14} \mathrm{C}$ from core MD95-2042. This core lies $75 \mathrm{~km}$ offshore of the southern Iberian Margin, thus outside the coastal upwelling zone. Based on dating of recent mollusks, Martins and Soares (2013) obtained a mean reservoir age value of about $470 \mathrm{yr}$ for the Algarve coast, which is influenced by upwelling. These authors also used ${ }^{14} \mathrm{C}$ measurements on mollusks found in archaeological sites in order to reconstruct the temporal variability of reservoir ages over the last 3 millennia. Martins and Soares (2013) document several brief spikes and invoke upwelling changes to explain them. As for the core from the Pakistan Margin, it may thus be safe to assume a rather large 
uncertainty (about $\pm 200 \mathrm{yr}$ ) in the reservoir age, which could have ranged between 300 and $700 \mathrm{yr}$ for the site of core MD95-2042.

\section{PALEOCLIMATIC STRATIGRAPHY}

Several independent paleoceanographic records were measured in core MD04-2876: organic carbon, nitrogen, and $\delta^{15} \mathrm{~N}$ (Pichevin et al. 2007); elemental profiles by XRF scanning (Böning et al. 2007); and contents of calcite and aragonite and $\mathrm{Sr} / \mathrm{Ca}$ ratios (Böning and Bard 2009). As described in these previous papers, all proxy records show marked variations that are in precise stratigraphic agreement and correlate with DO and $\mathrm{H}$ events (see more on the subject in the following section).

Figure 3 summarizes the stratigraphy of core MD04-2876 based on 3 independent paleoceanographic proxies: the \% of total organic carbon (TOC) directly linked to planktonic productivity (Pichevin et al. 2007); the \% of calcium carbonate $\left(\mathrm{CaCO}_{3}\right)$ controlled by its dissolution due to organic matter remineralization leading to acidification at mid-depth (Böning and Bard 2009); and the $\delta^{15} \mathrm{~N}$ ratio, a proxy for the denitrification intensity in the oxygen minimum zone, which is also linked to organic matter remineralization (Pichevin et al. 2007). Note the inverted scale with $\mathrm{CaCO}_{3}$ maxima (minima) corresponding to TOC minima (maxima). Geochemical measurements and analytical methods are described in our previous publications (Böning et al. 2007; Pichevin et al. 2007; Böning and Bard 2009). The high-resolution $\mathrm{CaCO}_{3}$ record (every $0.5 \mathrm{~cm}$ ) is based on Avaatech XRF scanner profiles calibrated with ICP-OES measurements as described by Böning et al. (2007).

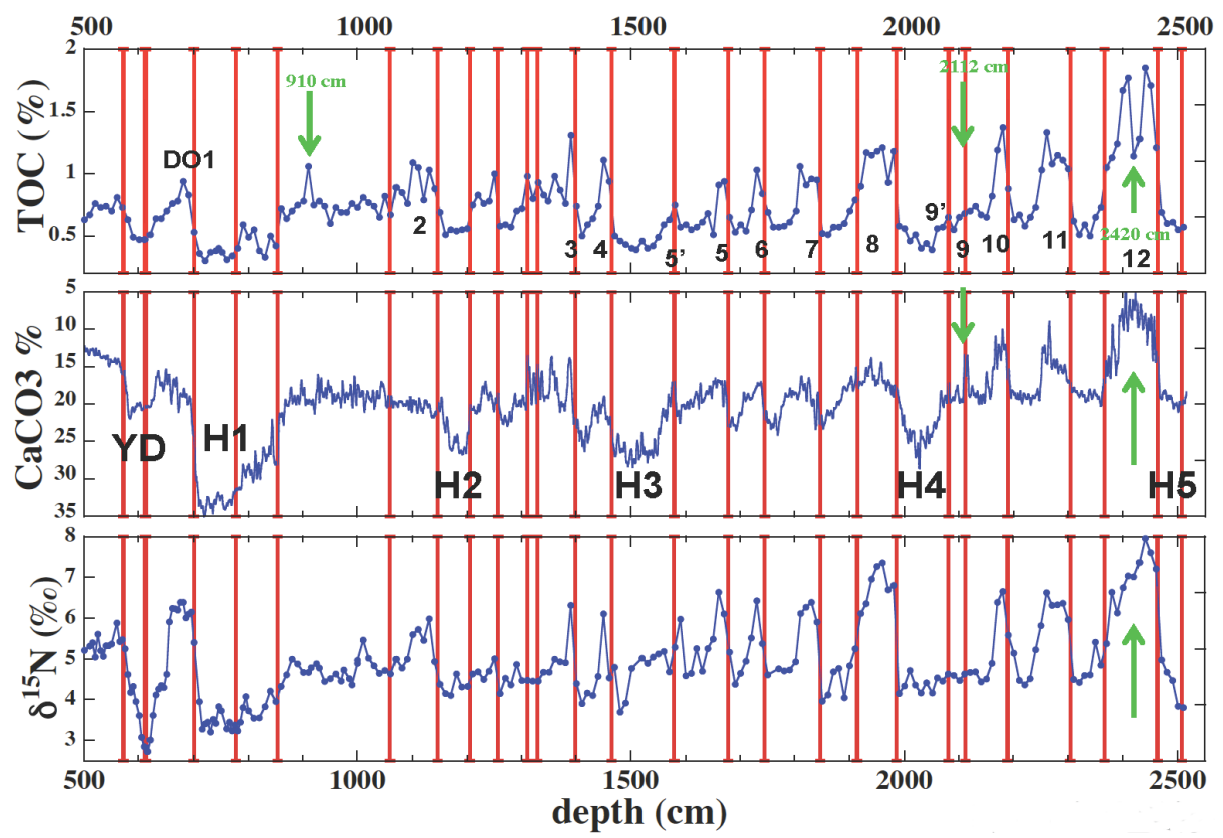

Figure 3 Geochemical records plotted versus depth in core MD04-2876: TOC, the $\%$ of total organic carbon (Pichevin et al. 2007); $\mathrm{CaCO}_{3}$, the \% of calcium carbonate (Böning et al. 2007; Böning and Bard 2009); and the $\delta^{15} \mathrm{~N}$ ratio (Pichevin et al. 2007). Note the inverted scale with $\mathrm{CaCO}_{3}$ maxima (minima) corresponding to TOC minima (maxima). These 3 geochemical proxies are related directly or indirectly to variations of the marine productivity linked to the Asian monsoon. Green arrows highlight specific examples of difficulties linked to event identification (TOC outlier at $910 \mathrm{~cm}$, local effect on organics at $2420 \mathrm{~cm}$, and short $\mathrm{CaCO}_{3}$ event at $2112 \mathrm{~cm}$, evidenced with the 0.5 -cm-resolution XRF record, but not seen with a $10-\mathrm{cm}$ discrete sampling for TOC and $\delta^{15} \mathrm{~N}$ ). Labels mark sections corresponding to DO and $\mathrm{H}$ events. The red vertical lines show the tie-points selected midway through the abrupt transitions between stadials and interstadials. 
Figure 3 shows geochemical proxies plotted versus depth for the section corresponding to the glacial and late glacial periods (from $5 \mathrm{~m}$ to the bottom of the core at around $25 \mathrm{~m}$ ). Already at this preliminary stage, DO interstadials can easily be recognized as TOC and $\delta^{15} \mathrm{~N}$ maxima and $\mathrm{CaCO}_{3}$ minima. The 5 Heinrich events correspond to TOC and $\delta^{15} \mathrm{~N}$ minima and $\mathrm{CaCO}_{3}$ maxima (these sections are recognized visually as lighter sections of homogenized oxic sediments; Pichevin et al. 2007; Böning and Bard 2009).

Paleoceanographic proxies are often complex indicators of environmental conditions with additional biological, chemical, or physical imprints superimposed on the main paleoceanographic control. These imperfections justify a multiproxy approach relying on the assumption that only common features are robust paleoceanographic events. For example (cf. Figure 3a green arrows), there is an isolated high TOC value at $910 \mathrm{~cm}$ that may be an outlier as it is not found in the $\mathrm{CaCO}_{3}$ and $\delta^{15} \mathrm{~N}$ records (nor in the total nitrogen record shown in Pichevin et al. [2007], or in any other records shown; Böning et al. 2007; Böning and Bard 2009). A similar problem arises with the TOC minimum around $2420 \mathrm{~cm}$ that is probably a local phenomenon specific to some markers (e.g. TOC and total N) but not all. As shown by Figure 3, a corresponding feature is not found in other proxies such as $\delta^{15} \mathrm{~N}$ and $\mathrm{CaCO}_{3}$ (or other high-resolution iron measurements, not shown). Consequently, these 2 isolated TOC features are probably not linked to the global H-DO variability and were not used in the tuning procedure.

The identification of significant paleoceanographic events should also take into account the stratigraphic resolution of the records. The high-resolution $(0.5 \mathrm{~cm}) \mathrm{CaCO}_{3}$ profile exhibits a short $(<10 \mathrm{~cm})$ minimum centered around $2112 \mathrm{~cm}$. The significance of this feature is confirmed by other high-resolution profiles (e.g. iron content, not shown). It is nonetheless absent in geochemical records (e.g. TOC and $\delta^{15} \mathrm{~N}$ ) measured on discrete samples every $10 \mathrm{~cm}$. As described in the following section, this $\mathrm{CaCO}_{3}$ feature corresponds to a rather short DO interstadial event (\#9 that lasted less than $200 \mathrm{yr}$ ) that will be used for tuning.

\section{CALENDAR TIMESCALE}

To build a calendar age scale for deep-sea sediment cores, we correlate the observed DO and $\mathrm{H}$ events to independently dated records. This tuning approach has been followed by several authors (Bond et al. 1997; Voelker et al. 2000; Bard et al. 2004a,b,c; Hughen et al. 2004a,b) who tuned North Atlantic records to the Greenland $\delta^{18} \mathrm{O}$ record measured on ice cores (GISP2, GRIP).

Several difficulties are associated with signal matching (see Reimer et al. 2013b and Heaton et al. 2013 , this issue). The first is the presence of substantial "noise" on both reference and undated records. This refers to uncorrelated structures that may be linked to genuine but local climatic changes, to additional effects on paleoclimatic proxies, and to analytical uncertainties on the proxy measurements. Obviously, it would be an error to try to correlate all the wiggles of this "noise" that can be as sizeable as the common signals.

A second major problem is that the wiggles used for matching may not be equivalent (or even homothetic) in the reference and undated records (e.g. the relative amplitude of temperature records may not be the same everywhere). Further problems can arise when using proxies that are related in a nonlinear way to the climatic parameter of interest (e.g. Greenland ice $\delta^{18} \mathrm{O}$ is a monotonous but not linear function of temperature).

For all these reasons, it is preferable to identify tie-points marking sharp transitions (assumed to be synchronous) rather than to try to automatically maximize an overall correlation coefficient. This underlines the importance of experts to identify the tie-points, based on their knowledge of the spe- 
cific advantages and pitfalls of individual paleoceanographic proxies and on their skills at identifying contemporaneous events in the 2 records via the correlations of a signal thought to reflect shared external events.

Advances in understanding the proxies used for signal matching have enabled increased reliability in such tuning. These advances led the IntCal Working Group to include data tuned to the Greenland $\delta^{18} \mathrm{O}$ record in the 2004 calibration curves (Hughen et al. 2004b; Reimer et al. 2004). However, the Greenland $\delta^{18} \mathrm{O}$ record is not the ideal reference for tuning. Its chronology based on counting "cryovarves" leads to relatively large errors of about a millennium for ages beyond $40 \mathrm{kyr}$ BP (Svensson et al. 2008). Furthermore, the Greenland $\delta^{18} \mathrm{O}$ record did not register clear signatures for the Heinrich events, unlike other records based on archives found in regions at lower latitudes (e.g. Bond et al. 1997; Bard et al. 2000; Wang et al. 2001).

Shackleton et al. (2004) proposed to use an alternative target curve for the tuning: the $\delta^{18} \mathrm{O}$ record of the Hulu Cave stalagmite, which has been accurately dated by U-Th (Wang et al. 2001). The advantage of using the Hulu record is that its chronology is precise and accurate, being equivalent to U-Th ages measured on corals also used for ${ }^{14} \mathrm{C}$ calibration purposes since 1993 (Stuiver and Reimer 1993; Bard et al. 1993). In addition, U-Th ages are absolute ages, independent of the successive revisions of the Greenland ice-core chronologies.

An apparent difficulty in using the Hulu record as a tuning target is that it does not appear straightforward to assume that North Atlantic paleoclimate records are synchronous with the precipitation changes within a cave in east China. Nevertheless, 15 years of paleoclimate research have demonstrated that large changes in the Asian monsoon have been paced by the H-DO millennial climate variability (Schulz et al. 1998; Wang et al. 2001; Altabet et al. 2002; see also Cheng et al. [2012] for a recent review and Zhang and Delworth [2005] for a theoretical study based on an ocean-atmosphere general circulation model).

Several detailed records over the last deglaciation have shown that the Asian monsoon response is synchronous within a century with the North Atlantic temperature changes (Dykoski et al. 2005; Sinha et al. 2005; Shakun et al. 2007). Steffensen et al. (2008) studied paleoclimatic records of the NGRIP core over the deglacial period, in particular 3 sharp transitions: the start of the Bølling event, and the start and the end of the Younger Dryas event. These authors compared the phase relationships between the ice $\delta^{18} \mathrm{O}$ record, a proxy for local temperature over Greenland, and the insoluble dust and $\mathrm{Ca}^{2+}$ concentration in ice. The $\mathrm{Ca}^{2+}$ mainly derives from calcium carbonate dust, which forms in Chinese semiarid areas under the control of wet-dry cycles (Ruth et al. 2007). Steffensen et al. (2008) showed that the precipitation changes in Asia occurred within 1 or 2 decades with respect to the temperature in Greenland. The advantage of their study is that all records have been measured in the same ice core, allowing a precise determination of phase lags.

For the IntCal09 calibration curve (Reimer et al. 2009), it was thus decided to include North Atlantic sediment records from the Cariaco Basin (Hughen et al. 2006) and the Iberian Margin (Bard et al. $2004 \mathrm{c}$ ) after retuning to the Hulu Cave $\delta^{18} \mathrm{O}$ record (Wang et al. 2001). The same records can be retuned with a new Hulu target curve (Hulu2), with a much higher resolution of U-Th and $\delta^{18} \mathrm{O}$ analyses (Edwards et al., submitted).

Obviously, it would be desirable to compare these ${ }^{14} \mathrm{C}$ data sets with an additional one constructed by tuning a marine record of the Asian monsoon to the Hulu record. This is precisely what can be done with the Pakistan Margin core MD04-2876 and its geochemical records of the marine biological productivity linked to the Asian monsoon. 
As in our previous work (Bard et al. 2004a,b,c), we have chosen a conservative approach for the stratigraphic tuning by using the minimum number of tie-points necessary to align the main H-DO events (about 25 tie-points for the range between 10 and $50 \mathrm{kyr} \mathrm{BP}$, see Figure 3). Points were selected midway through the abrupt transitions between stadials and interstadials to avoid identification ambiguity and artifacts from differences in resolution between records. These tie-points were chosen visually and the match was performed with the Linage software developed by Paillard et al. (1996).

Following our previous work on the Iberian Margin sediments (Bard et al. 2004a,b,c), it is useful to consider multiple proxies in the same undated archives in order to check the validity of the tiepoints. The TOC curve was used as the master undated record because it is considered a robust proxy for marine biological productivity (Müller and Suess 1979). We then verified the matches by cross-checking with both the $\delta^{15} \mathrm{~N}$ and the $\mathrm{CaCO}_{3}$ records. The previous section described specific difficulties and ways to circumvent them (e.g. local features and aliasing). Overall, the chosen ties were found to agree well across the various proxies within the undated record (Figure 3).

After tuning, the stratigraphy of core MD04-2876 can be transformed into a calendar timescale with linear interpolation between tie-points. The resulting comparisons between the Hulu Cave $\delta^{18} \mathrm{O}$ record and the TOC, $\mathrm{CaCO}_{3}$, and $\delta^{15} \mathrm{~N}$ records are shown in Figure 4. The overall agreement shows that east China and the Pakistan Margin registered the same millennial variability, even for brief events such as the DO interstadial 9, which lasted less than $200 \mathrm{yr}$ (green arrow). Figure 5 shows the equivalent panel for the Iberian Margin record published previously (Bard et al. 2004b,c; Reimer et al. 2009) after the stratigraphy core MD95-2042 has been retuned to the Hulu2 target curve.

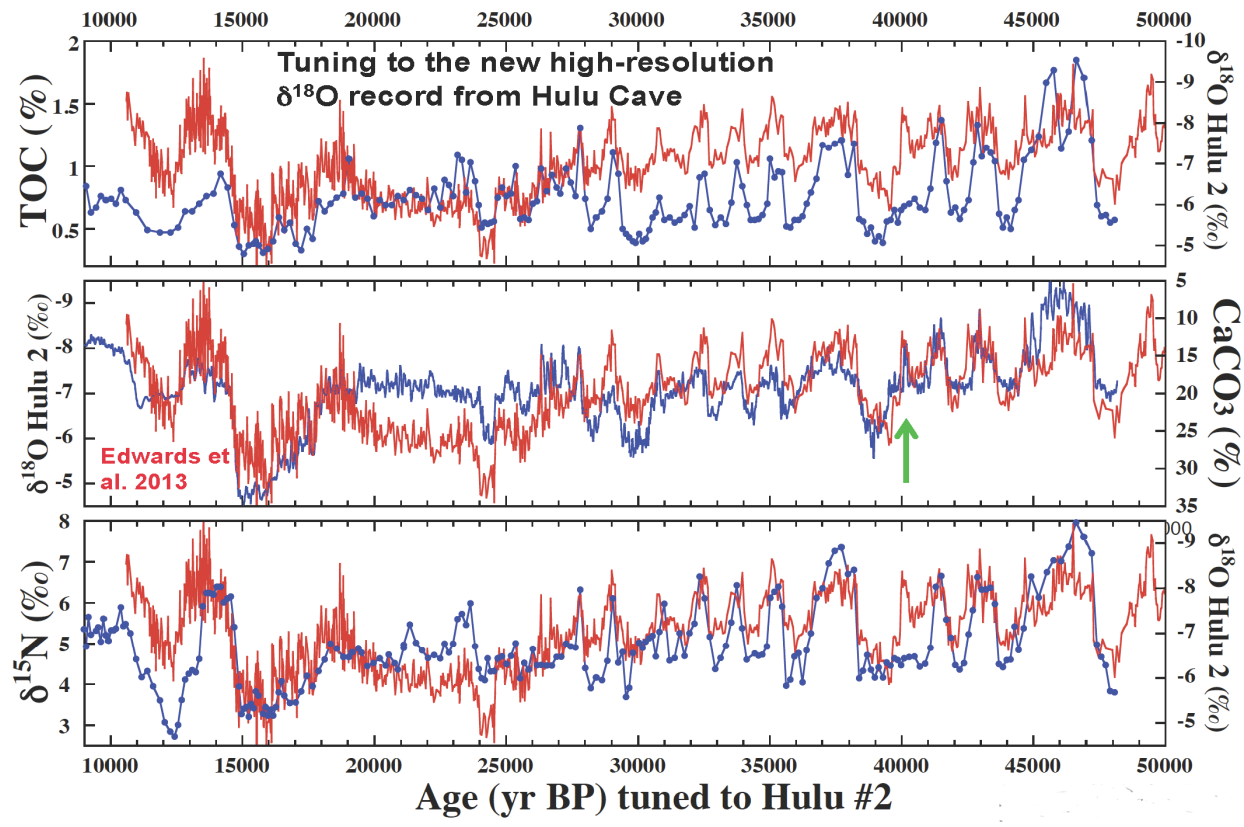

Figure 4 Geochemical records in core MD04-2876 from the Pakistan Margin and the Hulu Cave stalagmite plotted versus calendar age. The new Hulu Cave $\delta^{18} \mathrm{O}$ record is plotted versus its own original chronology based on high-resolution U-Th dating (Edwards et al., submitted). The MD04-2876 records are plotted versus the chronology based on tuning the tie-points shown in Figure 3. These points were matched visually to the Hulu Cave $\delta^{18} \mathrm{O}$ record with the Linage software (Paillard et al. 1996). The 3 panels illustrate the level of agreement between records after the tuning procedure. The green arrow indicates the brief DO9 interstadial, which lasted less than 2 centuries. Core MD04-2876 has a mean sedimentation rate of $51 \mathrm{~cm} / \mathrm{kyr}$ between 10 and $48 \mathrm{kyr}$ BP. 

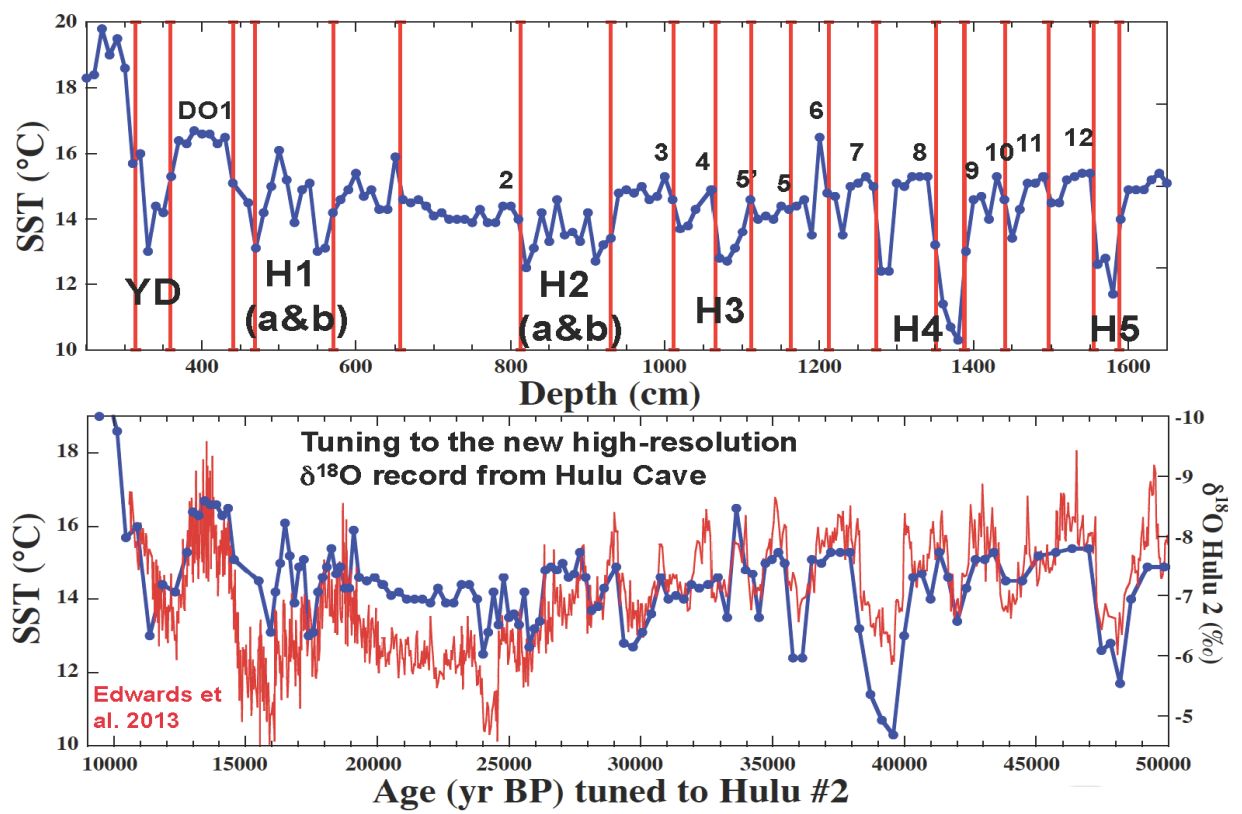

Figure 5 Summary of the retuning applied to core MD95-2042 from the Iberian Margin. See Bard et al. (2004a,b,c) for more details about various geochemical records and tuning strategy. The upper panel shows the sea surface temperature (SST) record based on alkenones plotted versus core depth. The labels mark the sections corresponding to DO and $\mathrm{H}$ events. Off the Iberian Margin, H1 and H2 contain 2 peaks (Bard et al. 2000). The red vertical lines show the tie-points selected for the tuning. The lower panel shows the new Hulu Cave $\delta^{18} \mathrm{O}$ record plotted versus its own original chronology based on high-resolution U-Th dating (Edwards et al., submitted). The MD95-2042 SST record is plotted versus the chronology based on tuning the tie-points shown in the upper panel. These points were matched visually to the Hulu record with the Linage software (Paillard et al. 1996). The lower panel illustrates the level of agreement between records after the tuning procedure. Core MD95-2042 has a mean sedimentation rate of $37 \mathrm{~cm} / \mathrm{kyr}$ between 10 and $40 \mathrm{kyr}$ BP.

\section{GAUSSIAN PROCESS MODEL}

In a companion paper (Heaton et al. 2013, this issue), a novel method is presented and used for the transfer of timescales from a reference record (in our case, Hulu2) to an undated record (Pakistan and Iberian margins, Cariaco Basin) when the 2 records have been matched via a series of externally identified tie-points. Intuitively, the aim is to elastically stretch or squash the reference chronology onto the new record using the selected ties while recognizing that the timescales in both records should represent age-depth models. This novel approach consists of a simple, 3-step process: creating an age-depth model for the reference record; transferring dating information from this across the identified tie-points to the undated record; and using this information to create another age-depth model for the undated record. The method is able to accurately incorporate the distinct uncertainties and dependencies created at each stage and justify their accumulation from one step to the next. This results in refined final chronologies.

In principle, many age-depth models could be utilized in the chronology transferal, although Heaton et al. (2013, this issue) suggest a Gaussian process (GP) since its use allows the chronology transfer to be achieved without resorting to intensive Monte Carlo computer simulation. It also allows the straightforward modeling of the dependence structure, which is inherent in all chronologies and can improve the quality and usefulness of the resultant estimates, especially if there is interest in the time elapsed between 2 depths. The resultant chronology not only consists of point estimates but also provides joint information for a set of depths, including their shared uncertainties. 
As shown by Heaton et al. (2013), the uncertainty in the transferred age-depth models tends to increase smoothly away from selected tie-points. However, the age estimate for a particular depth will not depend solely upon the uncertainty of the nearest tie-point. Instead, the novel method is able to borrow strength from the entire set of data points (ties and the original reference data). This strength borrowing is a result of the assumption that there is a smooth age-depth curve underlying both of the records. As a consequence, although the original observed depths in the reference record or the tie-point matchings may be relatively uncertain, the final age-depth model itself can be estimated more precisely by combining the information from all the data together. The interpolation method used is thus still able to provide useful age estimates, even at depths away from the tie-points.

To create the chronologies for the Pakistan and Iberian margins described in this paper (together with the updated timescale for the Cariaco Basin of Hughen et al. [2006]), the above transferal method was used but with a minor modification to use GP age-depth models for both the reference and undated records. The general approach set out in Heaton et al. (2013, this issue) for which this recommendation is made considers the situation where the reference does not have a pre-existing recognized timescale but only a collection of pointwise calendar age estimates. For the Hulu2 record, this is not the case and an OxCal-based timescale already exists (Edwards et al., submitted). For reasons of consistency, it was not felt this reference Hulu2 timescale should be recalculated. Instead, the Hulu2 age estimates were transferred via the tie-points to the relevant Pakistan or Iberian record before their final chronologies were formed using a GP. This still allowed the uncertainty information available at each stage of the transferal to be properly considered.

As verified by Heaton et al. (2013, this issue), the method is robust against the exclusion or inclusion of individual tie-points. It has also been tested with various values of the matching error between the tie-points identified in the target and tuned curves. Table 1 provides the maximum likelihood solution for cores MD04-2876 and MD95-2042, based on a tuning error of $100 \mathrm{yr}$, as mentioned in the previous section. The additional uncertainty arising from the Hulu2 age model is also incorporated when the information is transferred across using the elastic tie-pointing approach (see Heaton et al. [2013, this issue] for more details about the process applied to IntCal13 records).

There is potential to further test and improve the method presented by Heaton et al. (2013, this issue). The method currently relies on input by experts to identify the set of tie-points. One potential improvement could be to automate this tie-point selection process and to combine quantitatively the information based on different proxies. The method could also be tested to include sedimentological processes that are known to generate dependency between nearby levels. For example, bioturbation mixes sediments upward and smoothes out rapid changes of sedimentation rate and other properties (e.g. Bard et al. 1987). Mixing intensity is variable through time and could be even absent in anoxic environments. Bioturbation introduces asymmetry into the problem because the sediment is continuously mixed upward, while the layers below the bioturbation zone remain unaffected.

\section{IMPLICATIONS FOR RADIOCARBON CALIBRATION}

The timescales tuned for cores MD04-2876 and MD95-2042 provide calendar age estimates for each individual ${ }^{14} \mathrm{C}$ age (see rightmost columns in Table 1). Columns 6 and 10 list the calendar ages obtained by linear interpolation between tie-points and by the refined Gaussian process (GP), respectively. As sedimentation rates are quite regular for both sediment cores (Figures 1 and 2), the difference between linear and GP interpolations is small on average (the arithmetic mean of the absolute value of the difference is about $20 \mathrm{yr}$ for core MD04-2876 and $50 \mathrm{yr}$ for MD95-2042). 
Error bars calculated through the Gaussian process clearly depend on the proximity with tie-points (Heaton et al. 2013, this issue). This leads to variable uncertainties ranging from 1 to 3 centuries. The unusually large error (600 yr) at $21.7 \mathrm{cal} \mathrm{kyr} \mathrm{BP}$ for the Iberian Margin is clearly linked to the absence of tie-point around $7 \mathrm{~m}$ in that core (see the upper panel of Figure 5). Ultimately, this is linked to the climatic stability of the last glacial maximum with a lack of signal structure to correlate records.

The resulting pairs of ${ }^{14} \mathrm{C}$ and calendar ages can then be used to calculate $\Delta{ }^{14} \mathrm{C}$ values (Table 1 , columns 8 and 12) and be plotted along with the previous IntCal04, IntCal09, and IntCal13 calibration curves (Figures 6, 7, 8). Data from the Pakistan and Iberian margins are evenly spread between 12 and $50 \mathrm{cal} \mathrm{kyr} \mathrm{BP.} \mathrm{Both} \mathrm{data} \mathrm{sets} \mathrm{agree} \mathrm{well} \mathrm{when} \mathrm{they} \mathrm{show} \mathrm{overlapping} \mathrm{or} \mathrm{close} \mathrm{ages} \mathrm{(e.g.} \mathrm{around}$ $16,23.5,26,32.5,33.5$, and $38.7 \mathrm{cal} \mathrm{kyr} \mathrm{BP})$.

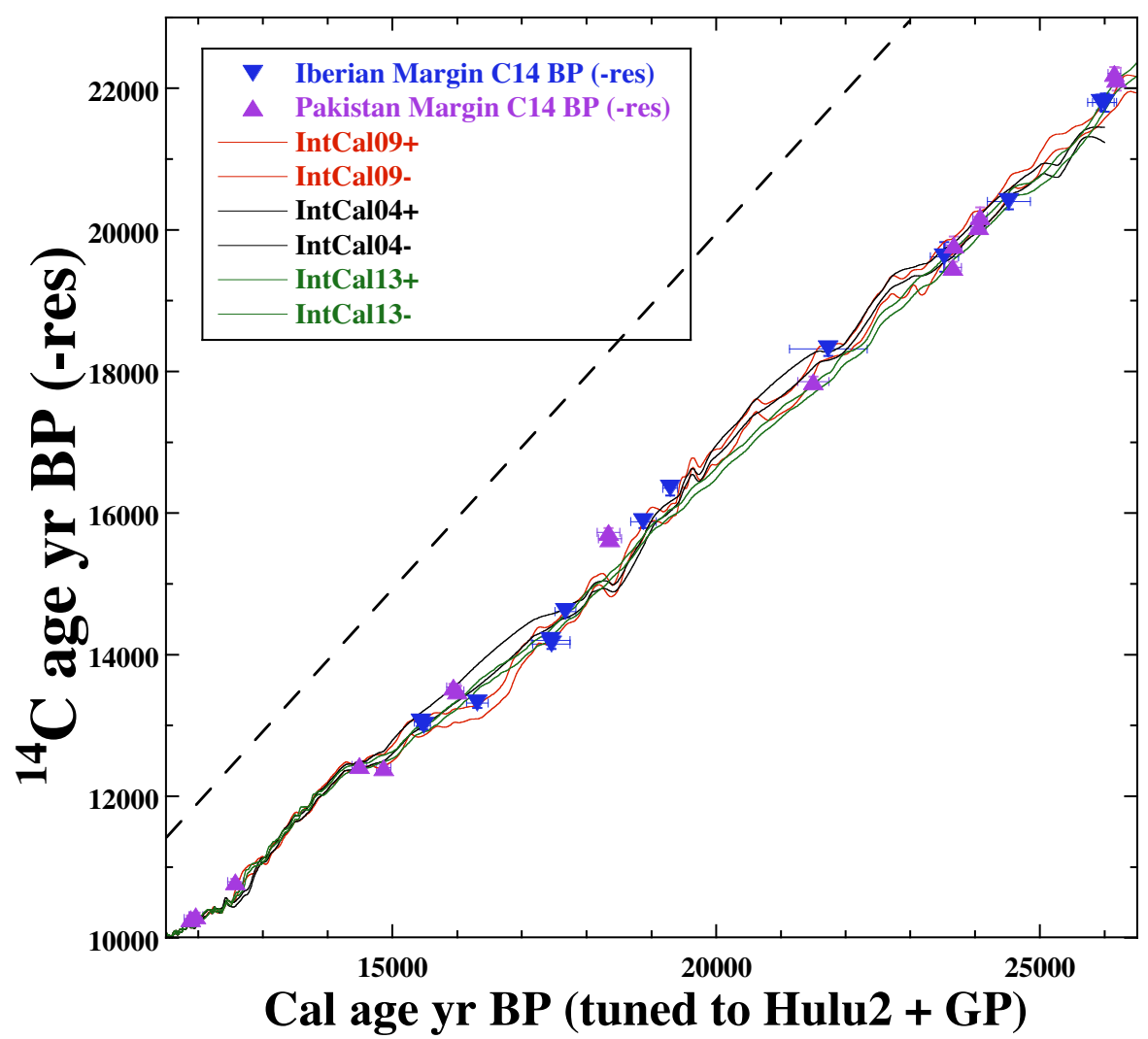

Figure $6{ }^{14} \mathrm{C}$ ages measured in cores MD04-2876 (purple triangles) and MD95-2042 (blue triangles) plotted versus calendar ages based on tuning to the new Hulu Cave $\delta^{18} \mathrm{O}$ record and Gaussian process interpolation between tie-points. The ${ }^{14} \mathrm{C}$ data are corrected for a site-specific reservoir age (see text). Uncertainties are plotted at the $1 \sigma$ level for both the ${ }^{14} \mathrm{C}$ and GP model. The dashed line is the one-toone line. These new data are compared with the IntCa104, IntCa109, and IntCal13 curves ( $\pm 1 \sigma$ range). See text for description and interpretation of agreements and discrepancies, notably the one between 28 and 31 cal kyr BP (Figure 7).

This agreement confirms the robustness of the stratigraphic technique. Even if both curves were tuned to the same Hulu target curve, it shows that matching a marine record influenced by the Asian monsoon is compatible with tuning a North Atlantic paleotemperature record typifying the H-DO 


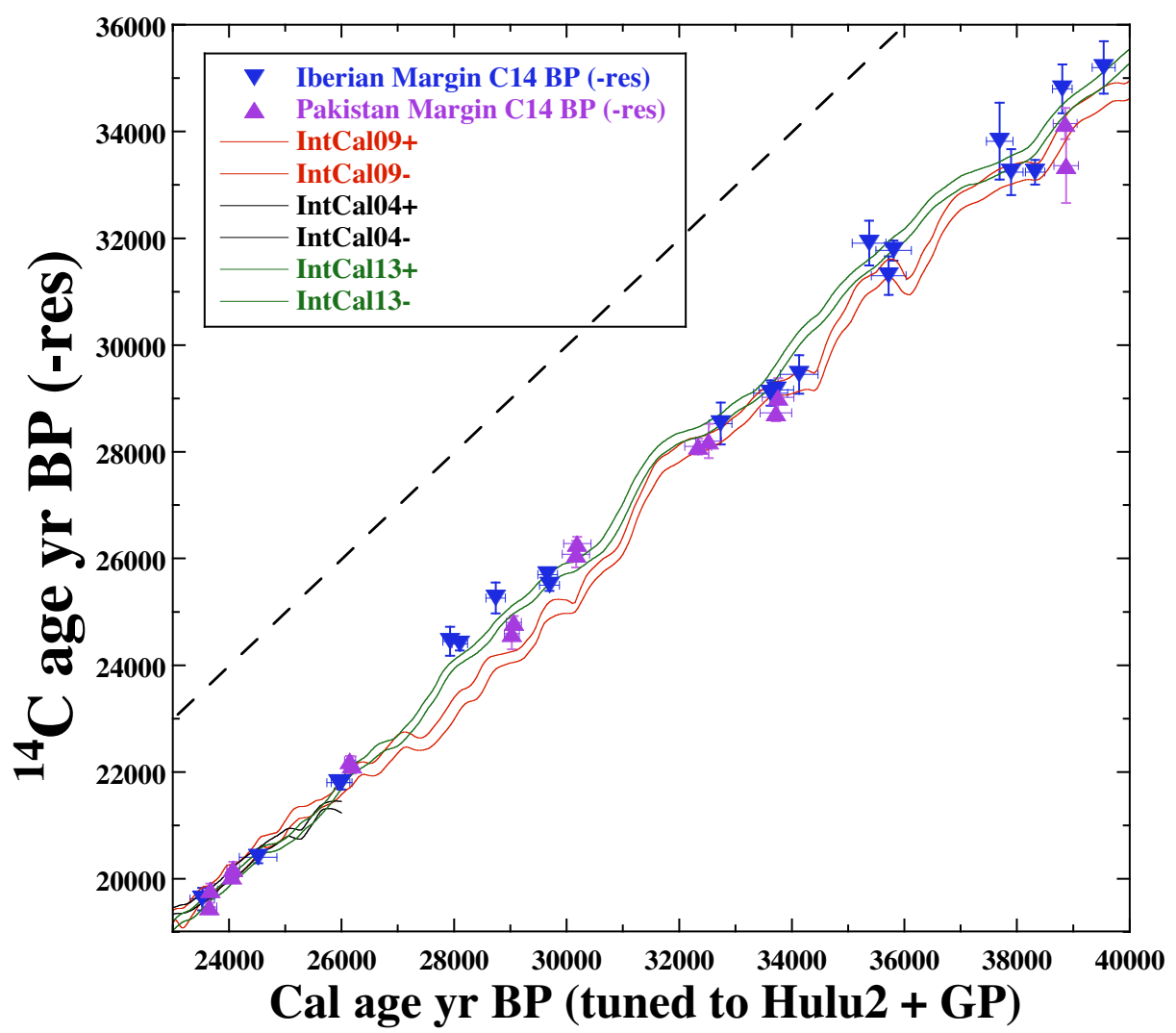

Figure 7 See Figure 6 caption

paleoclimate events. This observation is reassuring not only for our work, but also for authors studying other sediment records, notably the Cariaco Basin record (Hughen et al. 2006).

The Pakistan and Iberian margins data sets also agree with the previous IntCal04, IntCal09, and IntCal13 calibration curves. Iberian Margin data tuned to Hulu (first version by Wang et al. 2001) were already used to construct the IntCal09 curve, but their statistical weight was minimal, implying that the comparison is still meaningful. Over the last $26 \mathrm{kyr}$, the observed agreement provides a further justification for the stratigraphic method and for its use in the framework of the IntCal13 ${ }^{14} \mathrm{C}$ calibration (Reimer et al. 2013a, this issue; our numerical data tuned to Hulu2 were provided on 1 November 2010, following the IntCal Workshop in Belfast in June 2010).

At around $16 \mathrm{cal} \mathrm{kyr}$ BP (Figure 6), the data plot above the IntCal09 curve, but agree with the IntCal04 curve. This section corresponds to Heinrich event 1 (H1, 14.6-17.6 cal kyr BP) for which Cariaco data were included in the IntCal09 curve, leading to a clear discrepancy with the IntCal04 curve. This problem has previously been discussed by Reimer et al. (2009), based on the few samples then available in the $\mathrm{H} 1$ time range from the Bahamas speleothems and the Iberian Margin sediments. Since 2009, further evidence conflicting with the Cariaco ${ }^{14} \mathrm{C}$ record has come from U-Th and ${ }^{14} \mathrm{C}$ dating of a suite of corals collected offshore Tahiti in the framework of IODP (Durand et al. 2013, this issue), from the Japanese Lake Suigetsu plant macrofossils (Bronk Ramsey et al. 2012), and also directly from the Hulu Cave speleothem dated by ${ }^{14} \mathrm{C}$ and U-Th (Southon et al. 2012). 
Beyond 26 cal kyr BP (Figures 7, 8), the new data are compatible with the IntCal09 curve, except for the interval between 28 and $31 \mathrm{cal} \mathrm{kyr} \mathrm{BP}$ during which the Pakistan and Iberian data plot systematically above the IntCal09 curve by about 0.5 to $1 \mathrm{kyr}$. This group of $9{ }^{14} \mathrm{C}$ measurements broadly corresponds to the interval of Heinrich event 3 (29-31 cal kyr BP). The paleoceanographic proxies measured in the Pakistan Margin core show that the monsoon upwelling was weaker during this interval (Figure 3; see also Böning et al. 2007; Pichevin et al. 2007; Böning and Bard 2009), which is fully compatible with the continental proxies indicating weaker precipitations (Wang et al. 2001). Because it is related to upwelling, the ${ }^{14} \mathrm{C}$ reservoir age may have been smaller during this time period, which runs counter to explaining the observed discrepancy. In addition, the 2 samples dated around $28 \mathrm{cal} \mathrm{kyr} \mathrm{BP}$ occurred clearly later than H3. Overall, the agreement between the Pakistan and Iberian data between 28 and $31 \mathrm{cal} \mathrm{kyr} \mathrm{BP}$ suggests that the difference with the IntCal09 curve is genuine and that the ${ }^{14} \mathrm{C}$ calibration needed improvement in that time range. Indeed, our data agree with the IntCal13 curve in this interval (Figure 7). Although the Pakistan and Iberian Margin data were used to construct the IntCal13 curve, these data only represent about $7 \%$ of all available data in the 28-31 cal kyr BP time range (Reimer et al. 2013a, this issue). The observed agreement is thus still useful and confirms the accuracy of our data tuned to Hulu2.

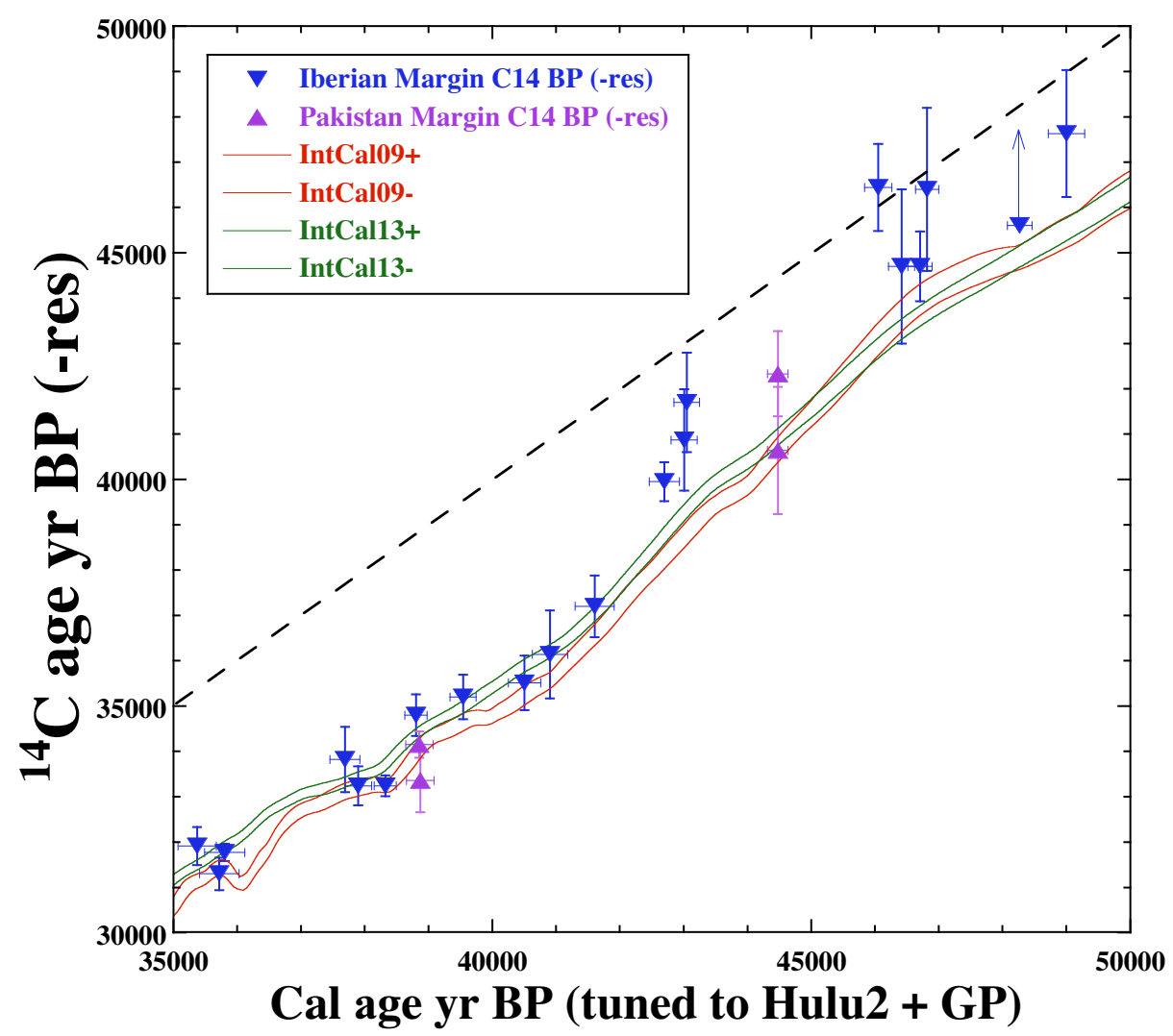

Figure 8 See Figure 6 caption

The time intervals including the 2 other Heinrich event intervals do not exhibit clear discrepancies between the IntCal09 and IntCal13 curves and the Pakistan or Iberian data sets. Nevertheless, the ${ }^{14} \mathrm{C}$ data density during H2 (23.5-26.5 cal kyr BP) still needs to be improved. Comparison with 
independent data from other archives will also be useful (cf. Figure 2 of Reimer et al. 2013a, this issue). During H5 (47-49 cal kyr BP), the data plot above the IntCal09 and IntCal13 curves, but the precision and accuracy of these very old ${ }^{14} \mathrm{C}$ ages are certainly not optimal to detect a discrepancy of a few centuries (in fact, the ${ }^{14} \mathrm{C}$ data agree with the IntCal09 and IntCal13 curves at the $2 \sigma$ level).

${ }^{14} \mathrm{C}$ calibration is a work in perpetual progress. In the future, we plan to further improve the Pakistan and Iberian margins' records by augmenting the ${ }^{14} \mathrm{C}$ database measured on planktonic foraminifera, by increasing the resolution and understanding of paleoceanographic proxies, by improving the tuning to the accurately data Hulu Cave record, and by comparing with atmospheric records to better constrain ${ }^{14} \mathrm{C}$ reservoir ages.

\section{ACKNOWLEDGMENTS}

We thank the support from INSU and the French Polar Institute IPEV, which provided the R/V Marion Dufresne during cruise MD143 CHAMAK in 2004. We thank Sophie Bieda for help with picking foraminifera. We acknowledge the helpful discussions about ${ }^{14} \mathrm{C}$ blanks with Ann McNichol (NOSAMS WHOI). Paleoclimate work at CEREGE is supported by the Comer Science and Education Foundation, the European Community (Project Past4Future), the College de France, and the EQUIPEX ASTER-CEREGE. ${ }^{14} \mathrm{C}$ dating of Pakistan Margin cores has been supported through the French CNRS-INSU Radiocarbon program and performed at the LMC14 laboratory with the Artemis facility in Saclay. Work on speleothems from China was supported by NSF Grants 0908792 , 1103403, and 1211299 to RLE and HC and by NSFC Grant 41230524 to HC. We thank Paula Reimer and an anonymous referee for useful reviews.

\section{REFERENCES}

Altabet MA, Higginson MJ, Murray DW. 2002. The effect of millennial-scale changes in Arabian Sea denitrification on atmospheric $\mathrm{CO}_{2}$. Nature 415(6868): 159-62.

Austin WEN, Bard E, Hunt JB, Kroon D, Peacock JD. 1995. The ${ }^{14} \mathrm{C}$ age of the Icelandic Vedde Ash: implications for Younger Dryas marine reservoir age corrections. Radiocarbon 37(1):53-62.

Bard E. 1988. Correction of accelerator mass spectrometry ${ }^{14} \mathrm{C}$ ages measured in planktonic foraminifera: paleoceanographic implications. Paleoceanography 3(6):635-45

Bard E. 1998. Geochemical and geophysical implications of the radiocarbon calibration. Geochimica et Cosmochimica Acta 62(12):2025-38.

Bard E. 2001. Paleoceanographic implications of the difference in deep-sea sediment mixing between large and fine particles. Paleoceanography 16(3):235-9.

Bard E, Arnold M, Duprat J, Moyes J, Duplessy J-C. 1987. Reconstruction of the last deglaciation: deconvolved records of $\delta^{18} \mathrm{O}$ profiles, micropaleontological variations and accelerator mass spectrometric ${ }^{14} \mathrm{C}$ dating. Climate Dynamics 1(2):101-12.

Bard E, Hamelin B, Fairbanks RG, Zindler A. 1990a. Calibration of the ${ }^{14} \mathrm{C}$ timescale over the past 30,000 years using mass spectrometric U-Th ages from Barbados corals. Nature 345(6274):405-10.

Bard E, Hamelin B, Fairbanks RG. 1990b. U-Th ages obtained by mass spectrometry in corals from Barbados: sea level during the past 130,000 years. Nature 346(6283):456-8.

Bard E, Arnold M, Fairbanks RG, Hamelin B. 1993. ${ }^{230} \mathrm{Th} /{ }^{234} \mathrm{U}$ and ${ }^{14} \mathrm{C}$ ages obtained by mass spectrometry on corals. Radiocarbon 35(1):191-9.

Bard E, Arnold M, Mangerud J, Paterne M, Labeyrie L, Duprat J, Melieres M-A, Sønstegaard E, Duplessy JC. 1994. The North Atlantic atmosphere-sea surface ${ }^{14} \mathrm{C}$ gradient during the Younger Dryas climatic event. Earth and Planetary Science Letters 126(4):275-87.

Bard E, Arnold M, Hamelin B, Tisnerat-Laborde N, Cabioch G. 1998. Radiocarbon calibration by means of mass spectrometric ${ }^{230} \mathrm{Th} /{ }^{234} \mathrm{U}$ and ${ }^{14} \mathrm{C}$ ages of corals: an updated database including samples from Barbados, Mururoa and Tahiti. Radiocarbon 40(3):108592.

Bard E, Rostek F, Turon J-L, Gendreau S. 2000. Hydrological impact of Heinrich events in the subtropical northeast Atlantic. Science 289(5483):1321-4.

Bard E, Rostek F, Ménot-Combes G. 2004a. A better radiocarbon clock. Science 303(5655):178-9.

Bard E, Rostek F, Ménot-Combes G. 2004b. Radiocarbon calibration beyond $20,000{ }^{14} \mathrm{C}$ yr B.P. by means of planktonic foraminifera of the Iberian Margin. Quaternary Research 61(2):204-14.

Bard E, Ménot-Combes G, Rostek F. 2004c. Present status of radiocarbon calibration and comparison records based on Polynesian corals and Iberian Margin sediments. Radiocarbon 46(3):1189-202. 
Bond G, Showers W, Cheseby M, Lotti R, Almasi P, deMenocal P, Priore P, Cullen H, Hajdas I, Bonani G. 1997. A pervasive millennial-scale cycle in North Atlantic Holocene and glacial climates. Science 278(5341):1257-66.

Bondevik S, Mangerud J, Birks HH, Gulliksen S, Reimer P. 2006. Changes in North Atlantic radiocarbon reservoir ages during the Allerød and Younger Dryas. Science 312(5779):1514-7.

Böning P, Bard E. 2009. Millennial/centennial-scale thermocline ventilation changes in the Indian Ocean as reflected by aragonite preservation and geochemical variations in Arabian Sea sediments. Geochimica et Cosmochimica Acta 73(22):6771-88.

Böning P, Bard E, Rose J. 2007. Towards direct, micronscale XRF elemental maps and quantitative profiles of wet marine sediments. Geochemistry, Geophysics, Geosystems 8(5): Q05004, doi:10.1029/ 2006GC001480.

Bronk Ramsey C, Staff RA, Bryant CL, Brock F, Kitagawa $\mathrm{H}$, van der Plicht J, Schlolaut G, Marshall MH, Brauer A, Lamb HF, Payne RL, Tarasov PE, Haraguchi T, Gotanda K, Yonenobu H, Yokoyama Y, Tada R, Nakagawa T. 2012. A complete terrestrial radiocarbon record for 11.2 to $52.8 \mathrm{kyr}$ B.P. Science 338(6105): $370-4$.

Cheng H, Sinha A, Wang X, Cruz FW, Edwards RL. 2012. The Global Paleomonsoon as seen through speleothem records from Asia and the Americas. Climate Dynamics 39(5):1045-62.

Cottereau E, Arnold M, Moreau C, Baqué D, Bavay D, Caffy I, Comby C, Dumoulin J-P, Hain S, Perron M, Salomon J, Setti V. 2007. Artemis, the new ${ }^{14} \mathrm{C}$ AMS at LMC14 in Saclay, France. Radiocarbon 49(2):2919.

Cutler KB, Gray SC, Burr GS, Edwards RL, Taylor FW, Cabioch G, Beck JW, Cheng H, Moore J. 2004. Radiocarbon calibration and comparison to $50 \mathrm{kyr}$ BP with paired ${ }^{14} \mathrm{C}$ and ${ }^{230} \mathrm{Th}$ dating of corals from Vanuatu and Papua New Guinea. Radiocarbon 46(3):1127-60.

Dansgaard W, Johnsen SJ, Clausen HB, Dahl-Jensen D, Gundestrup NS, Hammer CU, Hvidberg CS, Steffensen JP, Sveinbjörnsdóttir AE, Jouzel J, Bond G. 1993. Evidence for general instability of past climate from a 250-kyr ice-core record. Nature 364(6434): $218-20$.

Durand N, Deschamps P, Bard E, Hamelin B, Camoin G, Thomas AL, Henderson GM, Yokoyama Y, Matsuzaki H. 2013. Comparison of ${ }^{14} \mathrm{C}$ and U-Th ages in corals from IODP \#310 cores offshore Tahiti. Radiocarbon 55(4), this issue.

Dutta K, Bhushan R, Somayulu BLK. 2001. $\Delta$ R values for the northern Indian Ocean. Radiocarbon 43(2A): 483-8.

Dykoski CA, Edwards RL, Cheng H, Yuan D, Cai Y, Zhang M, Lin Y, Qing J, An Z, Revenaugh J. 2005. A high-resolution absolute-dated Holocene and deglacial Asian monsoon record from Dongge Cave, China.
Earth and Planetary Science Letters 233(1-2):71-86. Edwards RL, Beck JW, Burr GS, Donahue DJ, Chappell JMA, Bloom AL, Druffel ERM, Taylor FW. 1993. A large drop in atmospheric ${ }^{14} \mathrm{C} /{ }^{12} \mathrm{C}$ and reduced melting in the Younger Dryas, documented with ${ }^{230} \mathrm{Th}$ ages of corals. Science 260(5110):962-8.

Edwards RL, Cheng H, Wang YJ, Yuan DX, Kelly MJ, Kong XG, Wang XF, Burnett A, Smith E. 2013. A refined Hulu and Dongge Cave climate record and the timing of the climate change during the last glacial cycle. Earth and Planetary Science Letters, submitted.

Fairbanks RG, Mortlock RA, Chiu T-C, Cao L, Kaplan A, Guilderson TP, Fairbanks TW, Bloom AL, Grootes PM, Nadeau M-J. 2005. Radiocarbon calibration curve spanning 0 to 50,000 years BP based on paired ${ }^{230} \mathrm{Th} /{ }^{234} \mathrm{U} /{ }^{238} \mathrm{U}$ and ${ }^{14} \mathrm{C}$ dates on pristine corals. Quaternary Science Reviews 24(16-17):1781-96.

Ganssen GM, Peeters FJC, Metcalfe B, Anand P, Jung SJA, Kroon D, Brummer G-JA. 2011. Quantifying sea surface temperature ranges of the Arabian Sea for the past 20000 years. Climate of the Past 7:1337-49.

Goslar T, Arnold M, Bard E, Kuc T, Pazdur MF, RalskaJasiewiczowa M, Tisnerat N, Rózański K, Walanus A, Wicik B, Wiêckowski K. 1995. High concentration of atmospheric ${ }^{14} \mathrm{C}$ during the Younger Dryas cold episode. Nature 377(6548):414-7.

Haflidason H, Sejrup HP, Klitgaard Kristensen D, Johnsen S. 1995. Coupled response of the late glacial climatic shifts of northwest Europe reflected in Greenland ice cores: evidence from the northern North Sea. Geology 23(12):1059-62.

Heaton TJ, Bard E, Hughen K. 2013. Elastic tie-pointing - transferring chronologies between records via a Gaussian process. Radiocarbon 55(4), this issue.

Hughen KA, Overpeck JT, Lehman SJ, Kashgarian M, Southon J, Peterson LC, Alley R, Sigman DM. 1998. Deglacial changes in ocean circulation from an extended radiocarbon calibration. Nature 391(6662):658.

Hughen K, Lehman S, Southon J, Overpeck J, Marchal O, Herring C, Turnbull J. 2004a. ${ }^{14} \mathrm{C}$ activity and global carbon cycle changes over the past 50,000 years. Science 303(5655):202-7.

Hughen KA, Baillie MGL, Bard E, Beck JW, Bertrand CJH, Blackwell PG, Buck CE, Burr GS, Cutler KB, Damon PE, Edwards RL, Fairbanks RG, Friedrich M, Guilderson TP, Kromer B, McCormac G, Manning S, Bronk Ramsey C, Reimer PJ, Reimer RW, Remmele S, Southon JR, Stuiver M, Talamo S, Taylor FW, van der Plicht J, Weyhenmeyer CE. 2004b. Marine04 marine radiocarbon age calibration, $0-26 \mathrm{cal} \mathrm{kyr} \mathrm{BP.} R a-$ diocarbon 46(3): 1059-86.

Hughen K, Southon J, Lehman S, Bertrand C, Turnbull J. 2006. Marine-derived ${ }^{14} \mathrm{C}$ calibration and activity record for the past 50,000 years updated from the Cariaco Basin. Quaternary Science Reviews 25(23-24): 3216-27.

Libby WF. 1952. Radiocarbon Dating. Chicago: Univer- 
sity of Chicago Press.

Lourantou A, Lavric JV, Köhler P, Barnola J-M, Paillard D, Michel E, Raynaud D, Chappellaz D. 2010. Constraint of the $\mathrm{CO}_{2}$ rise by new atmospheric carbon isotopic measurements during the last deglaciation. Global Biogeochemical Cycles 24(2): GB2015, doi: 10.1029/2009GB003545.

Martins JMM, Soares AMM. 2013. Marine radiocarbon reservoir effect in southern Atlantic Iberian coast. $R a-$ diocarbon 55(3):1123-34.

McGee D, Broecker WS, Winckler G. 2010. Gustiness: the driver of glacial dustiness? Quaternary Science Reviews 29(17-18):2340-50.

Moreau C, Caffy I, Comby C, Delqué-Količ E, Dumoulin J-P, Hain S, Quiles A, Setti V, Souprayen C, Thellier B, Vincent J. 2013. Research and development of the Artemis ${ }^{14} \mathrm{C}$ AMS Facility: status report. Radiocarbon 55(2):331-7.

Müller PJ, Suess E. 1979. Productivity, sedimentation rate, and sedimentary organic matter in the oceans-I Organic carbon preservation. Deep-Sea Research 26(12):1347-62.

Nadeau M-J, Grootes PM, Voelker A, Bruhn F, Duhr A, Oriwall A. 2001. Carbonate ${ }^{14} \mathrm{C}$ background: Does it have multiple personalities? Radiocarbon 43(2A): $169-76$.

Paillard D, Labeyrie L, Yiou P. 1996. Macintosh program performs time-series analysis. Eos Transactions $A G U$ 77(39):379.

Pichevin L, Bard E, Martinez P, Billy I. 2007. Evidence of ventilation changes in the Arabian Sea during the Late Quaternary: implication for denitrification and nitrous oxide emission. Global Biogeochemical Cycles 21(4): GB4008, doi:10.1029/2006GB002852.

Rea DK. 1994. The paleoclimatic record provided by eolian dust deposition in the deep-sea the geologic history of wind. Reviews of Geophysics 32(2):159-95.

Reimer PJ, Reimer RW. 2001. A marine reservoir correction database and on-line interface. Radiocarbon 43(2A):461-3.

Reimer PJ, Baillie MGL, Bard E, Bayliss A, Beck WJ, Bertrand C, Blackwell PG, Buck CE, Burr GS, Cutler KB, Damon PE, Edwards RL, Fairbanks RG, Friedrich M, Guilderson TP, Hughen KA, Kromer B, McCormac FG, Manning S, Bronk Ramsey C, Reimer RW, Remmele S, Southon JR, Stuiver M, Talamo S, Taylor FW, van der Plicht J, Weyhenmeyer CE. 2004. IntCal04 terrestrial radiocarbon age calibration, 0-26 cal kyr BP. Radiocarbon 46(3):1029-58.

Reimer PJ, Baillie MGL, Bard E, Bayliss A, Beck JW, Blackwell PG, Bronk Ramsey C, Buck CE, Burr GS, Edwards RL, Friedrich M, Grootes PM, Guilderson TP, Hajdas I, Heaton TJ, Hogg AG, Hughen KA, Kaiser KF, Kromer B, McCormac FG, Manning SW, Reimer RW, Richards DA, Southon JR, Talamo S, Turney CSM, van der Plicht J, Weyhenmeyer CE. 2009. IntCa109 and Marine09 radiocarbon age calibration curves, 0-50,000 years cal BP. Radiocarbon 51(4): 1111-50.

Reimer PJ, Bard E, Bayliss A, Beck JW, Blackwell PG, Bronk Ramsey C, Buck CE, Cheng H, Edwards RL, Friedrich M, Grootes PM, Guilderson TP, Haflidason H, Hajdas I, Hatté C, Heaton TJ, Hoffman DL, Hogg AG, Hughen KA, Kaiser KF, Kromer B, Manning SW, Niu M, Reimer RW, Richards DA, Scott EM, Southon JR, Staff RA, Turney CSM, van der Plicht J. 2013a. IntCal13 and Marine13 radiocarbon age calibration curves $0-50,000$ years cal BP. Radiocarbon 55(4), this issue.

Reimer PJ, Bard E, Bayliss A, Beck JW, Blackwell PG, Bronk Ramsey C, Buck CE, Edwards RL, Friedrich M, Grootes PM, Guilderson TP, Haflidason H, Hajdas I, Hatté C, Heaton TJ, Hogg AG, Hughen KA, Kaiser KF, Kromer B, Manning SW, Reimer RW, Richards DA, Scott EM, Southon JR, Turney CSM, van der Plicht J. 2013b. Selection and treatment of data for radiocarbon calibration: an update to the International Calibration (IntCal) criteria. Radiocarbon 55(4), this issue.

Ruth U, Bigler M, Röthlisberger R, Siggaard-Andersen ML, Kipfstuhl S, Goto-Azuma K, Hansson ME, Johnsen SJ, Lu H, Steffensen JP. 2007. Ice core evidence for a very tight link between North Atlantic and east Asian glacial climate. Geophysical Research Letters 34(3): L03706, doi:10.1029/2006GL027876.

Schleicher M, Grootes PM, Nadeau M-J, Schoon A. 1998. The carbonate ${ }^{14} \mathrm{C}$ background and its components at the Leibniz AMS facility. Radiocarbon 40(1): $85-94$.

Schulz H, von Rad U, Erlenkeuser H. 1998. Correlation between Arabian Sea and Greenland climate oscillations of the past 110,000 years. Nature 393(6680):547.

Shackleton NJ, Fairbanks RG, Chiu T-C, Parrenin F. 2004. Absolute calibration of the Greenland time scale: implications for Antarctic time scales and for ${ }^{14}$ C. Quaternary Science Reviews 23(14-15):151322.

Shakun JD, Burns SJ, Fleitmann D, Kramers J, Matter A, Ai-Subary A. 2007. A high resolution, absolute-dated deglacial speleothem record of Indian Ocean climate from Socotra Island, Yemen. Earth and Planetary Science Letters 259(3-4):442-56.

Siani G, Paterne M, Michel E, Sulpizio R, Sbrana A, Arnold M, Haddad G. 2001. Mediterranean Sea surface radiocarbon reservoir age changes since the last glacial maximum. Science 294(5548): 1917-20.

Sikes EL, Samson CR, Guilderson TP, Howard WR. 2000. Old radiocarbon ages in the southwest Pacific Ocean during the last glacial period and deglaciation. Nature 405(6786):555-9.

Sinha A, Cannariato KG, Stott LD, Li H-C, You C-F, Cheng H, Edwards RL, Singh IB. 2005. Variability of southwest Indian summer monsoon precipitation dur- 
ing the Bølling-Allerød. Geology 33(10):813-6. Southon JR, Nelson DE, Vogel JS. 1990. A record of past ocean-atmosphere radiocarbon differences from the northeast Pacific. Paleoceanography 5(2):197-206.

Southon J, Noronha AL, Cheng H, Edwards RL, Wang Y. 2012. A high-resolution record of atmospheric ${ }^{14} \mathrm{C}$ based on Hulu Cave speleothem H82. Quaternary Science Reviews 33:32-41.

Staubwasser M, Sirocko F, Grootes PM, Erlenkeuser H. 2002. South Asian monsoon climate change and radiocarbon in the Arabian Sea during early and middle Holocene. Paleoceanography 17(4):1063, doi: 10.1029/2000PA000608.

Steffensen JP, Andersen KK, Bigler M, Clausen HB, Dahl-Jensen D, Fischer H, Goto-Azuma K, Hansson M, Johnsen SJ, Jouzel J, Masson-Delmotte V, Popp T, Rasmussen SO, Röthlisberger R, Ruth U, Stauffer B, Siggaard-Andersen ML, Sveinbjörnsdóttir ÁE, Svensson A, White JWC. 2008. High-resolution Greenland ice core data show abrupt climate change happens in few years. Science 321(5889):680-4.

Stuiver M, Grootes PM. 2000. GISP2 oxygen isotope ratios. Quaternary Research 53(3):277-84.

Stuiver M, Reimer PJ. 1993. Extended ${ }^{14} \mathrm{C}$ data base and revised CALIB $3.0{ }^{14} \mathrm{C}$ age calibration program. $R a$ diocarbon 35(1):215-30.

Stuiver M, Reimer PJ, Bard E, Beck JW, Burr GS, Hughen KA, Kromer B, McCormac G, van der Plicht J, Spurk M. 1998. INTCAL98 radiocarbon age calibration, 24,000-0 cal BP. Radiocarbon 40(3):104183.
Svensson A, Andersen KK, Bigler M, Clausen HB, DahlJensen D, Davies SM, Johnsen, SJ, Muscheler R, Parrenin F, Rasmussen SO, Röthlisberger R, Seierstad I, Steffensen JP, Vinther BM. 2008. A 60000 year Greenland stratigraphic ice core chronology. Climate of the Past 4:47-57.

Voelker AHL, Grootes PM, Nadeau M-J, Sarnthein M. 2000. Radiocarbon levels in the Iceland Sea from 25 $53 \mathrm{kyr}$ and their link to the Earth's magnetic field intensity. Radiocarbon 42(3):437-52.

von Rad U, Schaaf M, Michels KH, Schulz H, Berger WH, Sirocko F. 1999. A 5000-yr record of climate change in varved sediments from the oxygen minimum zone off Pakistan, northeastern Arabian Sea. Quaternary Research 51(1):39-53.

von Rad U, Sarnthein M, Grootes PM, Doose-Rolinski H, Erbacher J. 2003. ${ }^{14} \mathrm{C}$ ages of a varved last glacial maximum section off Pakistan. Radiocarbon 45(3): 467-77.

Waelbroeck C, Duplessy J-C, Michel E, Labeyrie L, Paillard D, Duprat J. 2001. The timing of the last deglaciation in North Atlantic climate records. Nature 412(6848):724-7.

Wang YJ, Cheng H, Edwards RL, An ZS, Wu JY, Shen C-C, Dorale JA. 2001. A high-resolution absolutedated Late Pleistocene monsoon record from Hulu Cave, China. Science 294(5550):2345-8

Zhang R, Delworth TL. 2005. Simulated tropical response to a substantial weakening of the Atlantic thermohaline circulation. Journal of Climate 18(12): 1853-60. 